\title{
Patients with more comorbidities have better detection of chronic conditions, but poorer management and control: findings from six middle-income countries
}

Grace Sum ${ }^{1 *}$, Gerald Choon-Huat Koh', Stewart W. Mercer ${ }^{2}$, Lim Yee Wei ${ }^{3}$, Azeem Majeed ${ }^{4}$, Brian Oldenburg ${ }^{5}$ and John Tayu Lee 1,4,5 $^{1}$

\begin{abstract}
Background: The burden of non-communicable diseases (NCDs) is rising rapidly in middle-income countries (MICs), where NCDs are often undiagnosed, untreated and uncontrolled. How comorbidity impacts diagnosis, treatment, and control of NCDs is an emerging area of research inquiry and have important clinical implications as highlighted in the recent National Institute for Health and Care Excellence guidelines for treating patients suffering from multiple NCDs. This is the first study to examine the association between increasing numbers of comorbidities with being undiagnosed, untreated, and uncontrolled for NCDs, in 6 large MICs.

Methods: Cross-sectional analysis of the World Health Organisation Study of Global Ageing and Adult Health (WHO SAGE) Wave 1 (2007-10), which consisted of adults aged $\geq 18$ years from 6 populous MICs, including China, Ghana, India, Mexico, Russia and South Africa (overall $n=41,557)$.

Results: A higher number of comorbidities was associated with better odds of diagnosis for hypertension, angina, and arthritis, and higher odds of having treatment for hypertension and angina. However, more comorbidities were associated with increased odds of uncontrolled hypertension, angina, arthritis, and asthma. Comorbidity with concordant conditions was associated with improved diagnosis and treatment of hypertension and angina.

Conclusion: Patients with more comorbidities have better diagnosis of chronic conditions, but this does not translate into better management and control of these conditions. Patients with multiple NCDs are high users of health services and are at an increased risk of adverse health outcomes. Hence, improving their access to care is a priority for healthcare systems.
\end{abstract}

Keywords: Comorbidity, Non-communicable diseases, Chronic conditions, Ageing, Health monitoring, Access to care

\section{What we know now and knowledge gaps}

- The burden of non-communicable diseases (NCDs) is rising rapidly in middle-income countries (MICs), where NCDs are often undiagnosed, untreated and uncontrolled.

\footnotetext{
* Correspondence: gracesum@u.nus.edu

'Saw Swee Hock School of Public Health, National University of Singapore, 12 Science Drive 2, Tahir Foundation Building, Singapore 117549, Singapore Full list of author information is available at the end of the article
}

- From the limited number of studies in high-income countries, there is preliminary evidence that more comorbidities negatively impact treatment and control of NCDs. There are also mixed results on how concordant and discordant comorbidities influence treatment and control.

- There is a specific knowledge gap in MICs on how more comorbidities with a NCD is associated with the diagnosis, treatment, and control of the NCD.

- There is also a knowledge gap in MICs on how concordant and discordant comorbidities with a 
NCD are associated with the diagnosis, treatment, and control of the NCD.

\section{What this study adds}

- A higher number of comorbidities was associated with better diagnosis of some NCDs.

- However, this did not translate into better management and control of NCDs. More comorbidities associated with even worse control of NCDs.

- Comorbidity with concordant conditions was associated with improved diagnosis and treatment, compared to comorbidity with discordant conditions.

- Patients with more comorbidities have better diagnosis of chronic conditions, but this does not translate into better management and control of these conditions. Patients with multiple NCDs are high users of health services and are at an increased risk of adverse health outcomes. Hence, improving their access to care is a priority for healthcare systems.

\section{Background}

Non-communicable diseases (NCDs) are the leading cause of global disease burden with $85 \%$ of premature mortality due to NCDs occurring in low- and-middle income countries [1]. In middle-income countries (MICs), there is a high prevalence of multiple chronic conditions in young adults, and not only in the elderly [2]. Poor chronic disease outcomes in MICs pose a major hurdle to attain the health target 3.4 of United Nation's Sustainable Development Goals, which is to reduce premature mortality from NCDs by a third by 2030 [3].

How comorbidity, defined as the presence of cooccurring NCDs in an individual $[4,5]$, impacts diagnosis, treatment, and control of NCDs is an emerging area of research inquiry and has important clinical implications as highlighted in the recent National Institute for Health and Care Excellence guidelines for treating patients suffering from multiple NCDs [6]. A small number of studies in high-income countries show mixed results on the implications of comorbidities on the management and control of single NCDs, such as hypertension or diabetes [7-10]. A study in the United States revealed that the proportion of persons with uncontrolled hypertension increased as the number of unrelated comorbid NCDs increased [9].

In contrast to this finding, a recent ecological study in the United Kingdom found that unrelated and related cooccurring NCDs could either be associated with better or worse treatment outcomes for patients with diabetes [8]. To the best of our knowledge, there are very few studies on this topic in MICs, and there is a need to fill the gap on comorbidities in MICs [11]. Findings from the small number of studies in high-income countries may not be applicable to MICs, as their health systems vary substantially and patients in MICs tend to have less frequent visits with well-trained healthcare providers $[2,12]$.

This study aims to examine how more comorbidities is associated with being undiagnosed, untreated, and uncontrolled for NCDs in 6 high-population MICs. We also investigate the odds of NCDs being undiagnosed, untreated, and uncontrolled, when comorbidities are concordant versus discordant. This paper considers the implications of the research findings for clinicians and policymakers on the revision of health structures and policies to improve management and control of NCDs in the context of MICs.

\section{Methods}

\section{Sample and data}

We used cross-sectional data from the World Health Organisation Study of Global Ageing and Adult Health (WHO SAGE) Wave 1 (2007-10) which collected nationally representative samples of people aged $50+$ years in China, Ghana, India, Mexico, Russia and South Africa, with a smaller sample of adults aged 18-49 years in each country for comparison [13]. SAGE contains information on sociodemographic characteristics, anthropometrics and biomarkers, NCDs, healthcare utilisation, quality of life and well-being, social cohesion, and impact on caregiving [13]. Face-to-face interviews were conducted in all countries, using a combination of computer-assisted personal interview, and paper and pencil [13].

The original total sample size of adults aged $\geq 18$ years was 44,089 (China: 15,009, India: 12,198, Ghana: 5563, Russia: 4350, Mexico: 2744, South Africa: 4225). We excluded those who had missing values on outcome variables and covariates (5.7\% of entire sample). Final sample size was 41,557 (China: 14,906, India: 11,159, Ghana: 5067, Russia: 4330, Mexico: 2618, South Africa: 3477).

\section{Variables}

Figure 4 in Appendix summarises predicting variables and outcomes.

\section{Chronic conditions}

SAGE collected information on 9 NCDs including hypertension, angina, arthritis, asthma, chronic lung disease (CLD), diabetes, cataract, stroke, and depression. All 9 NCDs had questions on self-reported diagnosis and treatment. Subjects self-reported the NCD if they answered affirmatively to: "Have you ever been diagnosed with ...? ". Subjects self-reported being treated for the NCD if they answered affirmatively to: "Have you been taking medication or other treatment for it during the ( ... last 2 weeks / ... last 12 months)?"

SAGE had symptom-based assessment or physical measurements for only 6 of 9 NCDs. Hence only these 6 of 9 NCDs could be assessed in this study for being 
undiagnosed, or for being uncontrolled. These were hypertension, angina, arthritis, asthma, CLD, and depression.

For hypertension, physical measurement of blood pressure was taken, and subjects with hypertension had systolic blood pressure $\geq 140 \mathrm{mmHg}$ or diastolic blood pressure $\geq 90$ mmHg [14]. For angina, depression, arthritis, asthma, and CLD, symptom-based assessments were according to validated symptom scales derived through a standard algorithm based on a set of symptomatic questions from SAGE survey (i.e. Rose questionnaire for angina $[15,16]$, Composite International Diagnostic Interview for depression [17, 18], receiver operating characteristic curve analysis that generated an algorithm for arthritis diagnosis by symptoms [19]). These methods were consistent with SAGE individual country reports published by WHO [20, 21]. Table 3 in Appendix shows details on the symptom-based assessment.

Table 1 Sample characteristics of the population of China, India, Ghana, Russia, Mexico, and South Africa

\begin{tabular}{|c|c|c|c|c|c|c|c|}
\hline & China & India & Ghana & Russia & Mexico & South Africa & Pooled \\
\hline Total (N) & 14,906 & 11,159 & 5,067 & 4,330 & 2,618 & 3,477 & 41,557 \\
\hline \multicolumn{8}{|l|}{ Sex (\%) } \\
\hline Male & 46.7 & 38.74 & 52.65 & 35.64 & 38.20 & 39.72 & 43.01 \\
\hline Female & 53.3 & 61.26 & 47.35 & 64.36 & 61.80 & 60.28 & 56.99 \\
\hline \multicolumn{8}{|l|}{ Marital Status (\%) } \\
\hline Not married & 16.75 & 22.34 & 41.70 & 46.26 & 41.29 & 55.88 & 29.19 \\
\hline Married & 83.25 & 77.66 & 58.30 & 53.74 & 58.71 & 44.12 & 70.81 \\
\hline \multicolumn{8}{|l|}{ Age Group (\%) } \\
\hline $18-29$ & 1.44 & 14.27 & 2.53 & 2.26 & 2.18 & 2.04 & 5.20 \\
\hline $30-39$ & 3.41 & 14.75 & 5.94 & 3.39 & 6.49 & 2.59 & 6.89 \\
\hline $40-49$ & 6.05 & 12.54 & 7.20 & 3.95 & 7.30 & 3.36 & 7.57 \\
\hline $50-59$ & 38.70 & 26.16 & 33.04 & 33.76 & 16.23 & 40.47 & 32.86 \\
\hline $60-69$ & 26.46 & 19.92 & 23.60 & 24.57 & 34.91 & 29.59 & 24.95 \\
\hline $70+$ & 23.94 & 12.37 & 27.69 & 32.06 & 32.89 & 21.94 & 22.53 \\
\hline \multicolumn{8}{|l|}{ Multimorbidity (\%) } \\
\hline 0 NCDs & 61.68 & 74.75 & 56.80 & 50.21 & 68.43 & 48.33 & 64.00 \\
\hline $1 \mathrm{NCD}$ & 24.47 & 10.47 & 26.02 & 11.13 & 14.76 & 33.95 & 17.00 \\
\hline 2 or more NCDs & 13.85 & 14.78 & 17.18 & 38.66 & 16.81 & 17.72 & 19.00 \\
\hline Mean number of NCDs & 1.03 & 1.41 & 1.23 & 1.88 & 1.36 & 1.40 & 1.11 \\
\hline \multicolumn{8}{|l|}{ Education Level (\%) } \\
\hline No schooling & 23.93 & 45.18 & 50.74 & 0.95 & 17.07 & 24.04 & 30.09 \\
\hline Primary or lower & 35.66 & 25.79 & 23.03 & 9.01 & 59.43 & 47.66 & 31.20 \\
\hline Secondary & 21.27 & 12.47 & 5.51 & 18.15 & 10.62 & 14.75 & 15.44 \\
\hline Tertiary or higher & 19.14 & 16.55 & 20.72 & 71.89 & 12.87 & 13.55 & 23.27 \\
\hline \multicolumn{8}{|l|}{ Wealth Quintile (\%) } \\
\hline Q1 (lowest) & 19.03 & 17.85 & 19.44 & 17.78 & 20.59 & 20.13 & 18.82 \\
\hline Q2 & 19.82 & 19.23 & 19.62 & 19.40 & 20.55 & 20.19 & 19.67 \\
\hline Q3 & 20.01 & 19.14 & 19.76 & 19.98 & 18.56 & 19.64 & 19.62 \\
\hline Q4 & 20.66 & 21.02 & 20.70 & 20.35 & 20.66 & 20.07 & 20.68 \\
\hline Q5 (highest) & 20.48 & 22.75 & 20.49 & 22.49 & 19.63 & 19.96 & 21.20 \\
\hline \multicolumn{8}{|l|}{ Location (\%) } \\
\hline Rural & 50.87 & 74.53 & 59.05 & 24.32 & 26.70 & 33.62 & 52.49 \\
\hline Urban & 49.13 & 25.47 & 40.95 & 75.68 & 73.30 & 66.38 & 47.51 \\
\hline \multicolumn{8}{|l|}{ Insurance (\%) } \\
\hline No insurance & 12.97 & 95.91 & 63.77 & 0.48 & No data & 82.17 & 48.14 \\
\hline With insurance (mandatory/voluntary) & 87.03 & 4.09 & 36.23 & 99.52 & No data & 17.83 & 51.86 \\
\hline
\end{tabular}




\section{Predicting variables}

The first predicting variable was number of comorbidities. Subjects were categorised by number of diagnosed comorbidities: 0, 1, 2, 3 and 4+ comorbidities. The second predicting variable was co-occurrence of each NCD with only concordant NCDs, only discordant NCDs, and only depression. Concordant NCDs were those that represented parts of the same overall pathophysiologic risk profile [7]. For example, studies considered diabetes and hypertension "concordant" due to similar pathophysiologic risk profiles or were more likely the focus of a similar disease complex and management plan [7, 22]. Conditions considered "discordant" were not directly related in pathogenesis or did not share an underlying predisposing factor [9]. For example, asthma and arthritis are considered "discordant" to diabetes and hypertension [9]. For our study, concordant sets of NCDs included (i) hypertension, angina, stroke, diabetes [9, 22]; (ii) diabetes, cataract [23]; (iii) asthma, CLD [24]. Two NCDs, arthritis and depression, did not have any concordant NCDs.

\section{Outcomes}

Firstly, we examined the associations between being undiagnosed, untreated, and uncontrolled for NCDs with increasing comorbidity, and secondly, the associations between being undiagnosed, untreated and uncontrolled for NCDs when the NCD co-occurs with only concordant NCDs, only discordant NCDs, and only depression.

Undiagnosed subjects did not have self-reported diagnosis of the NCD by a medical professional but had the NCD based on SAGE assessment. Untreated subjects self-reported previous diagnosis of the NCD by a medical professional but self-reported not having treatment (medications, lifestyle changes, therapy, and/or counselling). Subjects who did not have treatment in the last 2 weeks and in the last 12 months were referred to in this study as ('unT-last 2 weeks') and ('unT-last 12 months'), respectively. Uncontrolled subjects self-reported being both diagnosed and treated for the NCD, but had symptoms of the NCD based on SAGE assessment. Uncontrolled subjects who had treatment in the last 2 weeks were referred to as 'unC-T-last 2 weeks' and those who had treatment in the last 12 months were referred to as 'unC-T-last 12 months'. Figure 5 and Table 4 in Appendix describe the detailed definitions of being undiagnosed, untreated, and uncontrolled.

\section{Covariates}

Covariates were age (18-49 years, 50-64 years, $65+$ years), sex, marital status (married, not married), education (primary or less, secondary, tertiary and above), wealth quintiles, residence (rural, urban), and health insurance (with/without insurance).

\section{Statistical analysis}

We summarised subject characteristics by country with pooled data. For each NCD, we examined the prevalence of subjects with $0,1,2,3$, and 4+ comorbid conditions.

For the $6 \mathrm{NCDs}$ that had symptom-based assessment, we presented the prevalence of undiagnosed subjects as their number of comorbidities increased from 0 to $1,2,3$, and $4+$. For all 9 NCDs, we presented prevalence of untreated subjects as the number of comorbidities increased from 0 to $1,2,3$, and 4+. For the 6 NCDs that had symptom-based assessment, we presented the prevalence of uncontrolled subjects as the number of comorbidities increased from 0 to $1,2,3$, and $4+$. In addition, we presented the prevalence of being undiagnosed, untreated, and uncontrolled when each NCD co-occurred with only concordant NCDs, only discordant NCDs, and only depression.

Table 2 Prevalence of undiagnosed, untreated, and uncontrolled subjects for each non-communicable disease

\begin{tabular}{|c|c|c|c|c|c|c|c|c|c|c|}
\hline & & \multicolumn{9}{|c|}{ Non-communicable disease (\%) } \\
\hline & & $\begin{array}{l}\text { Hypertension } \\
(n=9778)\end{array}$ & $\begin{array}{l}\text { Angina } \\
(n=3274)\end{array}$ & $\begin{array}{l}\text { Arthritis } \\
(n=540)\end{array}$ & $\begin{array}{l}\text { Asthma } \\
(n= \\
153)\end{array}$ & $\begin{array}{l}\text { Chronic Lung } \\
\text { Disease } \\
(n=2455)\end{array}$ & $\begin{array}{l}\text { Diabetes } \\
(n=2735)\end{array}$ & $\begin{array}{l}\text { Cataract }^{a} \\
(n=3739)\end{array}$ & $\begin{array}{l}\text { Depression } \\
(n=1129)\end{array}$ & $\begin{array}{l}\text { Stroke } \\
(n=1205)\end{array}$ \\
\hline \multirow{5}{*}{$\begin{array}{l}\text { Prevalence } \\
\text { of subjects } \\
(\%)\end{array}$} & 1. Undiagnosed & 59.11 & 62.23 & 42.76 & 55.48 & 50.27 & NA & NA & 67.57 & NA \\
\hline & $\begin{array}{l}\text { 2a. unT-last } 2 \text { weeks } \\
\text { (untreated in the last } \\
2 \text { weeks) }\end{array}$ & 34.89 & 42.04 & 58.39 & 46.21 & 91.19 & 33.76 & NA & 70.45 & 57.66 \\
\hline & $\begin{array}{l}\text { 2b. unT-last } 12 \text { months } \\
\text { (untreated in the last } \\
12 \text { months) }\end{array}$ & 17.43 & 18.11 & 31.74 & 27.84 & 84.84 & 24.48 & 59.98 & 63.54 & 42.47 \\
\hline & $\begin{array}{l}\text { 3a. unC-T-last } 2 \text { weeks } \\
\text { (treated in the last } 2 \\
\text { weeks, and uncontrolled) }\end{array}$ & 71.14 & 83.61 & 77.41 & 78.00 & 81.72 & NA & NA & 50.34 & NA \\
\hline & $\begin{array}{l}\text { 3b. unC-T-last } 12 \text { months } \\
\text { (treated in the last } 12 \\
\text { months, and uncontrolled) }\end{array}$ & 66.82 & 77.77 & 72.81 & 77.89 & 70.05 & NA & NA & 62.21 & NA \\
\hline
\end{tabular}

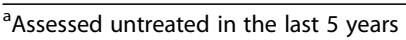


a. Odds of being undiagnosed for each non-communicable disease (NCD), with increasing comorbidity

${ }^{+}$Multivariable logistic regression adjusted for age, sex, marital status, education level, income level, residence, insurance, and country fixed effects

Reference group: 0 comorbidities

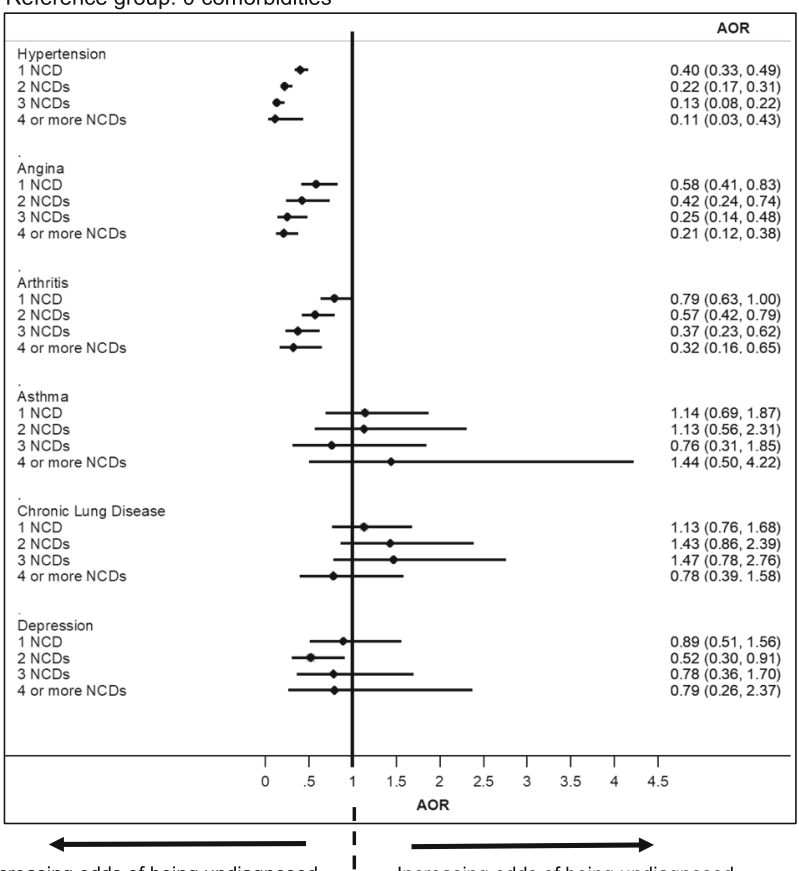

Decreasing odds of being undiagnosed Increasing odds of being undiagnosed

b. Odds of being undiagnosed for each non-communicable disease (NCD), with only concordant NCDs, only discordant NCDs, and only depression

${ }^{+}$Multivariable logistic regression adjusted for age, sex, marital status, education level, income level, residence, insurance, and country fixed effects

^Concordant NCDs: (a) hypertension, angina, diabetes, stroke; (b) asthma, chronic lung disease.

Reference group: concordant NCDs and/or discordant NCDs and/or depression

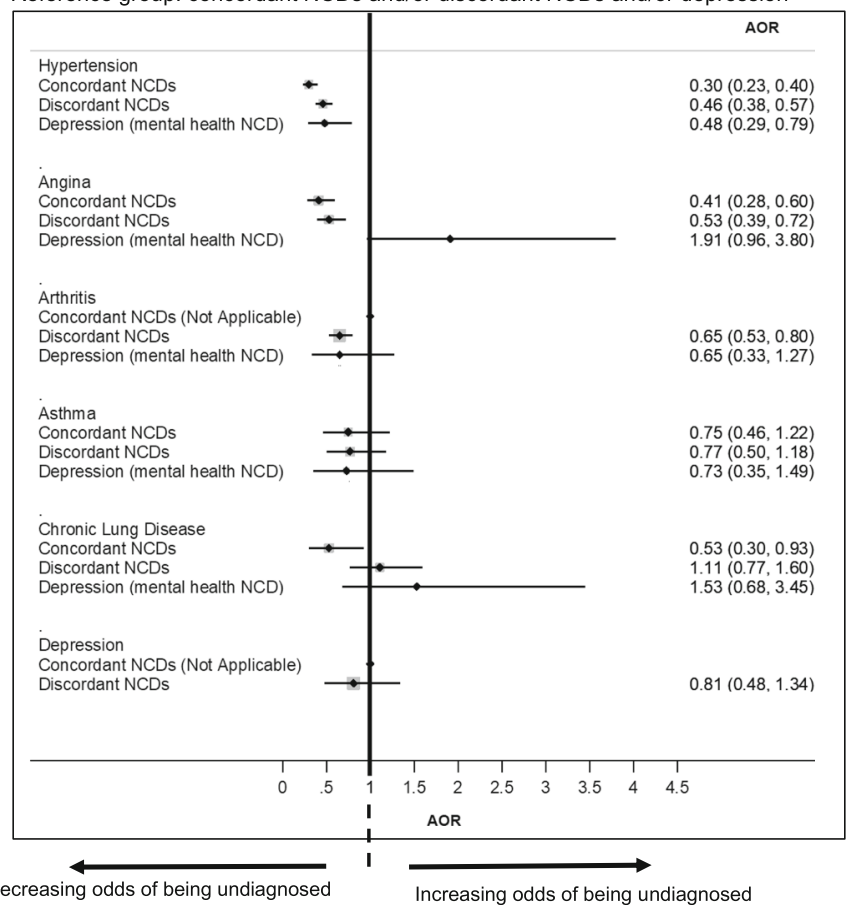

Fig. 1 (See legend on next page.) 
(See figure on previous page.)

Fig. 1 a Odds of being undiagnosed for each non-communicable disease (NCD), with increasing comorbidity. ${ }^{+}$Multivariable logistic regression adjusted for age, sex, marital status, education level, income level, residence, insurance, and country fixed effects. b Odds of being undiagnosed for each non-communicable disease (NCD), with only concordant NCDs, only discordant NCDs, and only depression. ${ }^{+}$Multivariable logistic regression adjusted for age, sex, marital status, education level, income level, residence, insurance, and country fixed effects. $\wedge$ Concordant NCDs: (a) hypertension, angina, diabetes, stroke; (b) asthma, chronic lung disease

We conducted a series of multivariable logistic regression analyses. For each NCD, we obtained adjusted odds ratios (AORs) of being undiagnosed, untreated and uncontrolled: Firstly, in association with greater number of comorbidities, and secondly, in association with the co-occurrence of only concordant NCDs, versus only discordant NCDs, and versus only depression. We adjusted for country fixed effects and covariates in all the regression models. The data analyses were weighted to account for the complex, multistage design of the SAGE survey. We performed statistical analyses using Stata 15.1(StataCorp).

\section{Results}

\section{Sample characteristics}

We presented subjects' characteristics by country in Table 1 . Median age was $58(\mathrm{IQR}=51-68)$ years. The prevalence of subjects with 2 or more NCDs was overall $19 \%$, and was $38.7 \%$ in Russia, $17.7 \%$ in South Africa, $17.2 \%$ in Ghana, $16.8 \%$ in Mexico, $14.8 \%$ in India, and $13.9 \%$ in China. Using pooled data, $43.0 \%$ were male, $22.5 \%$ were aged above 70 years, $61.3 \%$ had primary school education or less, $18.8 \%$ were from the lowest income quintile, $52.5 \%$ resided in rural areas, and $48.1 \%$ did not have insurance. Table 5 in Appendix displays the prevalence of subjects with $0,1,2,3$, and 4+ comorbidities for each NCD.

\section{Undiagnosed NCDs}

Table 2 shows the prevalence of subjects undiagnosed for each NCD, which ranged from $42.8 \%$ for undiagnosed arthritis to $62.2 \%$ for undiagnosed angina.

More comorbidities were associated with decreased odds of undiagnosed hypertension, angina and arthritis, but not for asthma, CLD, and depression (Fig. 1a). Comorbidity with concordant conditions was associated with decreased odds of undiagnosed hypertension and angina, but not for arthritis, asthma, CLD, and depression (Fig. 1b).

\section{Untreated NCDs}

Table 2 shows the prevalence of subjects untreated for each NCD, with highest prevalence for CLD (91.2\% 'unT-last 2 weeks', $84.8 \%$ 'unT-last 12 months'), and lowest prevalence for diabetes (33.8\% 'unT-last 2 weeks') and hypertension (17.4\% 'unT-last 12 months').

More comorbidities were associated with decreased odds of untreated hypertension and angina, but not arthritis, asthma, CLD, diabetes, depression and stroke for
'unT-last 12 months' (Fig. 2a). Similar results were seen for untreated hypertension and angina for 'unT-last 2 weeks' (Figure 6a in Appendix). In contrast, comorbidity was associated with increased odds of untreated diabetes.

Comorbidity with concordant conditions was associated with decreased odds of untreated hypertension and angina, but not arthritis, asthma, CLD, diabetes, depression and stroke (Fig. 2b, Figure 6b in Appendix).

\section{Uncontrolled NCDs}

Table 2 shows the prevalence of subjects uncontrolled for each NCD, with highest prevalence for angina (83.6\% 'unC-T-last 2 weeks'; $77.8 \%$ 'unC-T-last 12 months'), and lowest prevalence for depression (50.3\% 'unC-T-last 2 weeks'; $62.2 \%$ 'unC-T-last 12 months').

More comorbidities were associated with increased odds of uncontrolled hypertension, angina, arthritis, and asthma, but not CLD and depression for 'unC-T-last 12 months' (Fig. 3a). Similar results were seen for 'unC-Tlast 2 weeks' (Figure 7a in Appendix).

Comorbidity with concordant conditions was not associated with decreased nor increased odds of being uncontrolled for all NCDs (Fig. 3b, Figure 7b in Appendix).

Tables 6-15 in Appendix show prevalence of being undiagnosed, untreated and uncontrolled for each NCD, in association with greater comorbidity, and with having only concordant NCDs, only discordant NCDs, and only depression.

\section{Discussion \\ Principal findings}

More comorbidities were associated with better diagnosis of hypertension, angina and arthritis, and better odds of having treatment for hypertension and angina. However, more comorbidities were associated with worse control of hypertension, angina, arthritis, and asthma.

Comorbidity with concordant conditions was associated with decreased odds of undiagnosed and untreated hypertension and angina. Comorbidity with concordant conditions was not associated with decreased nor increased odds of being uncontrolled for NCDs.

\section{Previous literature}

Our finding on the positive effect of comorbidities on diagnosis is consistent with the small number of existing articles. Subjects with more comorbidities likely resulted in 
a. Adjusted odds ratios of being untreated in the last 12 months (unT-last 12 months) for each non-communicable disease (NCD), with increasing comorbidity

${ }^{+}$Multivariable logistic regression adjusted for age, sex, marital status, education level, income level, residence, insurance, and country fixed effects

Note: Cataract was only assessed for being untreated in the last 5 years

Reference group: 0 comorbidities

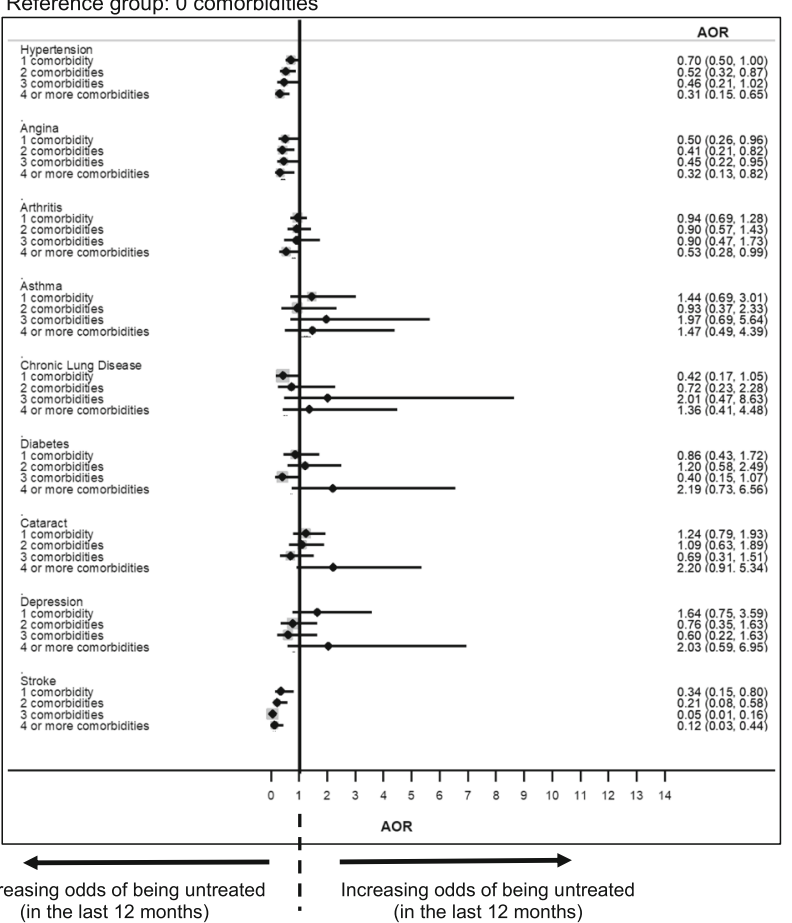

b. Odds of being untreated in the last 12 months (unT-last 12 months) for each non-communicable disease (NCD), with only concordant NCDs, only discordant NCDs, and only depression

${ }^{+}$Multivariable logistic regression adjusted for age, sex, marital status, education level, income level, residence, insurance, and country fixed effects ${ }^{\wedge}$ Concordant NCDs: (a) hypertension, angina, diabetes, stroke; (b) diabetes, cataract; (c) asthma, chronic lung disease.

Note: Cataract was only assessed for being untreated in the last 5 years

Reference group: concordant NCDs and/or discordant NCDs and/or depression

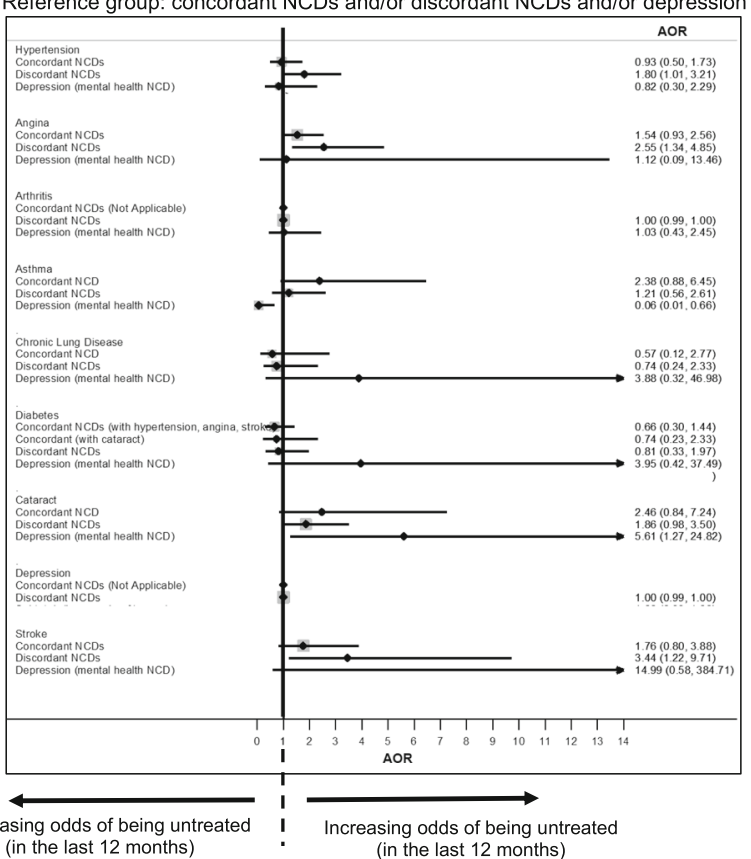

Fig. 2 (See legend on next page.) 
(See figure on previous page.)

Fig. 2 a Adjusted odds ratios of being untreated in the last 12 months (unT-last 12 months) for each non-communicable disease (NCD), with increasing comorbidity. ${ }^{+}$Multivariable logistic regression adjusted for age, sex, marital status, education level, income level, residence, insurance, and country fixed effects. Note: Cataract was only assessed for being untreated in the last 5 years. $\mathbf{b}$ Odds of being untreated in the last 12 months (unT-last 12 months) for each non-communicable disease (NCD), with only concordant NCDs, only discordant NCDs, and only depression. ${ }^{+}$Multivariable logistic regression adjusted for age, sex, marital status, education level, income level, residence, insurance, and country fixed effects^Concordant NCDs: (a) hypertension, angina, diabetes, stroke; (b) diabetes, cataract; (c) asthma, chronic lung disease. Note: Cataract was only assessed for being untreated in the last 5 years.

more frequent visits to, and interactions with multiple health providers. Healthcare professionals were more likely to detect previously undiagnosed co-occurring conditions $[25,26]$, such as hypertension, angina, and arthritis in this particular study. More comorbidities and increased frequency of healthcare visits were likely associated with a greater tendency for routinely taken blood pressure measurements to indicate hypertension, and for patients to selfreport "chest pains" and arthritis symptoms [27-29]. For other conditions such as CLD and depression that require non-routine checks and are less self-reported, they may still be undiagnosed despite more patients having more comorbidities and more frequent healthcare visits [30-33].

Our finding on more comorbidities being associated with decreased odds of untreated hypertension and angina was not consistent with the small amount of existing literature, which mostly showed that comorbidity was associated with increased odds of untreated conditions. Existing studies showed that patients had difficulty coping with complex treatment regiments from polypharmacy, and had poor adherence from adverse drug events and high out-of-pocket expenditures on medicines [6,34-36]. The difference in our findings and current literature is likely explained by our study examining only whether subjects were taking treatment or not, and did not assess if treatment was adequate, in terms of adherence to medicines (i.e. dose, frequency, duration, administration (e.g. techniques for subcutaneous insulin injections or inhaler use), route (oral, parenteral)), and to lifestyle modifications [37]. Our study showed that with more comorbidities, subjects had higher odds of taking treatment, but we expect that in reality, with more comorbidities, odds of treatment adherence and having adequate treatment would decline.

Our finding on more comorbidities being associated with poorer control is also consistent with the little amount of existing literature. The difficulty controlling NCDs tend to be exacerbated with more co-occurring conditions, and patients with comorbidities were less likely to have certain NCDs addressed [7, 9, 10]. Our study also showed that concordant comorbidities were associated with decreased odds of both undiagnosed and untreated hypertension and angina. Previously undiagnosed concordant NCDs may have a higher tendency to be simultaneously diagnosed during consultations with physicians for the primary NCD of interest, and concordant NCDs are more likely to have better coordination of care $[6,9,38]$.

Our study's finding that discordant conditions were not associated with poorer control of NCDs is generally in contrast to the literature. The small number of existing studies have revealed that discordant comorbidities, which have different pathophysiology and management plans, compromise the quality of care of the patient $[7,9,39]$. For example, a study in the United States on hypertension found that patients with discordant conditions were less likely to have controlled hypertension [9]. The existing literature is from high-income countries with likely higher adherence to treatment [40-42], and in contrast, adherence to treatment may be lower in MICs due to financial constraints and lower health literacy [36, 43]. Hence this non-adherence in MICs may explain the lack of difference between concordant versus discordant comorbidities in the association with control of NCDs.

\section{Strengths and limitations}

This is the first study on high-population MICs that investigates the associations between comorbidity and the odds of being undiagnosed, untreated, and uncontrolled for NCDs. Self-reported diagnosis of NCDs may be under-reported and symptom-based assessment of NCDs may not correlate with true medical status [13, 44, 45]. Additionally, stigma could be a reason for under-reporting of depression in MICs [32, 46]. These limitations may have implications on under-estimations of associations in the study. However, previous work suggests this may not be a substantial problem as SAGE incorporated measures to minimise these issues [45]. There may be differential survey responses across countries. However, the survey methodology included strategies to detect and correct for systematic reporting biases in health interview surveys, such as vignette methods and objective performance tests [44]. Strategies were used to improve data comparability, such as utilising common definitions of concepts, common data collection methods and translations, rigorous sample design, and post-hoc harmonisation [44].

Additionally, this survey only asked if subjects were taking treatment (medicines, lifestyle changes), but did not measure self-reported treatment adherence (i.e. dosage, 
a. Odds of being uncontrolled (unC-T-last 12 months) for each non-communicable disease (NCD), with increasing comorbidity ${ }^{+}$Multivariable logistic regression adjusted for age, sex, marital status, education level, income level, residence, insurance, and country fixed effects

Reference group: 0 comorbidities

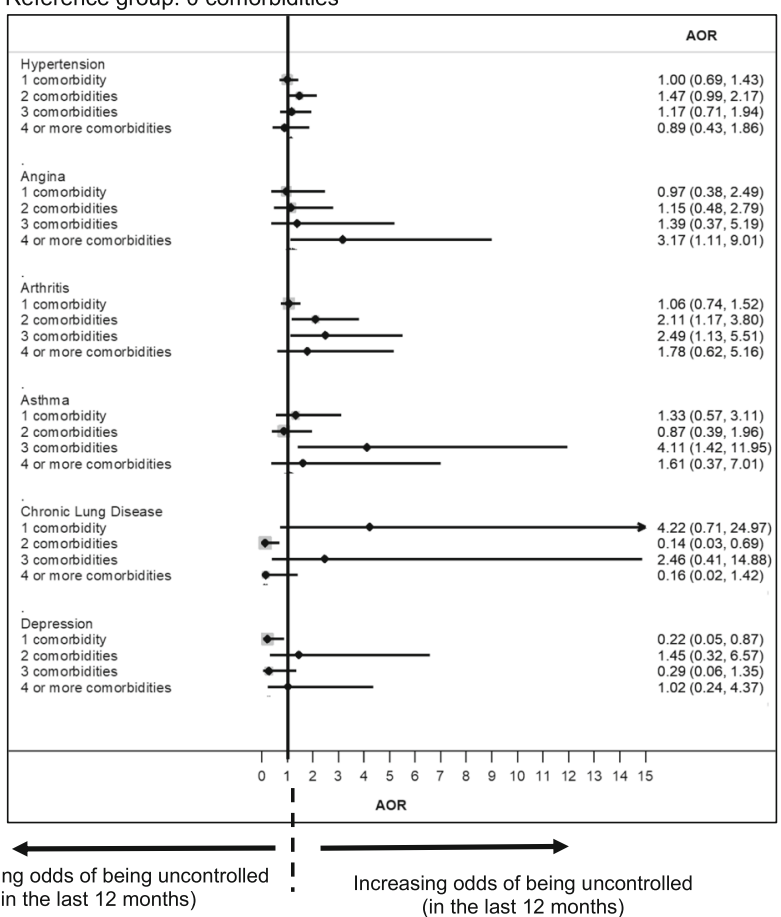

b. Odds of being uncontrolled (unC-T-last 12 months) for each non-communicable disease (NCD), with only concordant NCDs, only discordant NCDs, and only depression

${ }^{+}$Multivariable logistic regression adjusted for age, sex, marital status, education level, income level, residence, insurance, and country fixed effects ${ }^{\wedge}$ Concordant NCDs: (a) hypertension, angina, diabetes, stroke; (b) diabetes, cataract; (c) asthma, chronic lung disease.

Reference group: concordant NCDs and/or discordant NCDs and/or depression

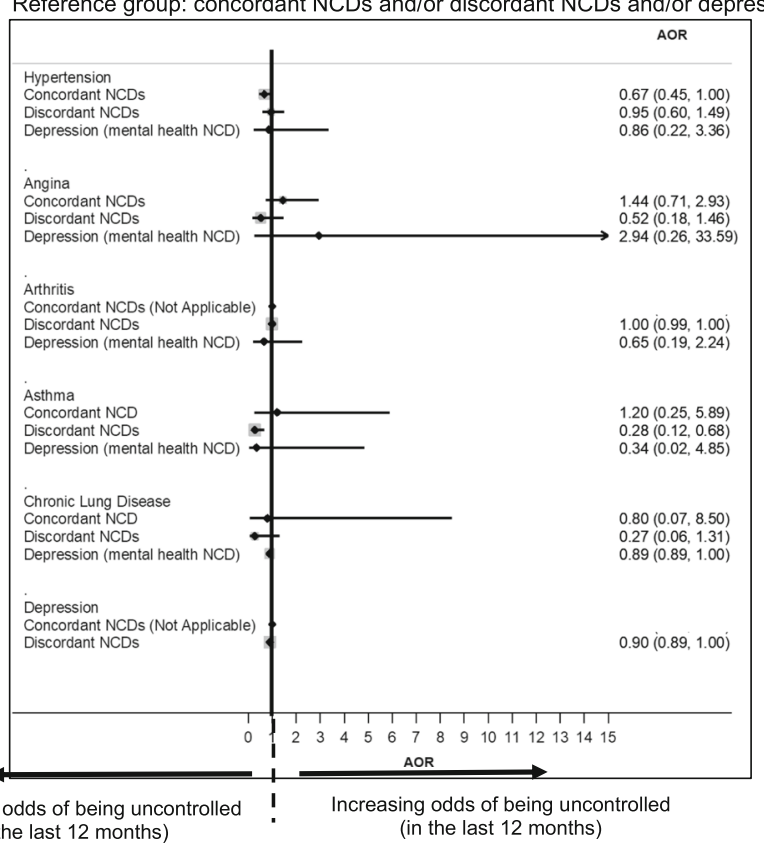

Decreasing odds of being uncontrolled (in the last 12 months)

Fig. 3 (See legend on next page.) 
(See figure on previous page.)

Fig. 3 a Odds of being uncontrolled (unC-T-last 12 months) for each non-communicable disease (NCD), with increasing comorbidity.

${ }^{+}$Multivariable logistic regression adjusted for age, sex, marital status, education level, income level, residence, insurance, and country fixed effects.

b Odds of being uncontrolled (unC-T-last 12 months) for each non-communicable disease (NCD), with only concordant NCDs, only discordant

NCDs, and only depression. ${ }^{+}$Multivariable logistic regression adjusted for age, sex, marital status, education level, income level, residence,

insurance, and country fixed effects. ^Concordant NCDs: (a) hypertension, angina, diabetes, stroke; (b) diabetes, cataract; (c) asthma, chronic

lung disease

frequency, duration, etc) [37]. There are limitations of the Rose questionnaire for assessing angina, including it being short in length, and that subjects with mental health disorders may be more likely to have false positive results [47]. However, large cohort studies showed that the Rose questionnaire had good predictive ability, and false positives from individuals with mental health conditions may be minimal [47-50]. This study did not adjust for the number of visits to a general practitioner in clinics to avoid possible over-adjustment bias. The associations between more comorbidities with better detection of previously undiagnosed NCDs [51], could be mediated by more clinic visits and interactions with healthcare professionals from having more comorbidities [12, 25, 26, 52]. The study was based on 9 NCDs, so future work could examine more conditions. For example, a large-scale Scotland study included 40 NCDs [53]. The study's cross-sectional design does not allow for causal interpretations, and studies that use prospective cohort designs could examine how comorbidities cause treatment and control of NCDs in subjects that are followed-up prospectively, such as over a few years [6].

\section{Clinical and policy implications}

Our study revealed that subjects with more comorbidity had better detection of NCDs, but control was worse with more comorbidity. There are three principle possible explanations. First, it may be related to poor access to care, whereby patients with multiple chronic conditions are getting treatment for their conditions (perhaps from a pharmacy) but there is a lack of access to care from the primary care system [5457]. It could also relate to cost, such as a lack of comprehensive universal coverage fee at the point of care [36, 58-60]. Second, it could be from suboptimal adherence to medications $[59,60]$. It is well documented that adherence drops as polypharmacy rises $[34,36,61]$. The lack of intentional ongoing monitoring by physicians and allied health professionals might compound this problem, as regular follow-up could include checks on adherence and reinforce the importance of taking the prescribed medications. Third, it could be due to a lack of effectiveness of medication prescribed for each condition in patients with multiple chronic conditions [62]. For most treatments of individual NCDs, the evidence is based on randomised controlled trials which exclude patients with multiple NCDs [62-64]. Thus what works in a patient with a single condition, may not work in a patient with the same NCD with comorbidities [65].
In reality, the problem may be a combination of these three possibilities. Primary healthcare clinicians need to improve the follow up on patients, in order to assess possible discontinuation of certain treatments due to adverse drug events, and the financial constraints that limit patients' ability to go for follow up check-ups and refilling prescriptions [36, 56, 57]. Another clinical implication is on prioritising NCDs, whereby clinicians should assess NCD profiles of patients, prioritise treatment for patients who would have the greatest clinical benefit of better management and control, and consider personal preferences of patients for managing various NCDs [6, 66-68].

Policies could prioritise NCDs that have higher prevalence or burden, such as focusing on lowering out-of-pocket expenditures for follow-up visits to healthcare providers and medicines [36, 69]. Policies also need to address continual accessibility to healthcare after first diagnosis. In MICs, it is not uncommon for patients to travel from rural residences to the urban areas to seek medical treatment, limiting their ability to regularly visit healthcare services and continue treatment, which results in suboptimal control of NCDs [52, 70, 71]. In addition, there are complexities of insurance policies. Health insurance from employers may be limited to certain districts or urban areas in MICs, and it is possible that healthcare for different conditions are covered by health providers in different physical locations [72, 73]. This problem aggravates the already existing fragmentation of care from utilising multiple health providers and services [53, 74].

Fragmented healthcare is a challenge for patients, policymakers, and clinicians. Reorganising healthcare structures particularly primary care, would benefit individuals with multiple chronic conditions who often have difficulty managing treatment due to polypharmacy, have multiple health providers and medical appointments, high financial burden, and suboptimal control of conditions [6, 11, 53, 74].

\section{Conclusion}

Patients with multiple chronic conditions may have better detection of some chronic conditions, but this does not translate into better management of these conditions. As these patients are high users of health services and are at increased risk of adverse health outcomes, improving their access to care is a priority for health systems. Clinical guidelines should move away from the current focus on single diseases and be tailored to better suit the needs of patients with multiple chronic conditions. 


\section{Appendix}

\begin{tabular}{|c|c|c|}
\hline $\begin{array}{l}\text { Predicting Variables } \\
\text { 1. Multimorbidity: }\end{array}$ & $\begin{array}{l}\text { Outcome Variables } \\
\text { 1. Odds of being undiagnosed }\end{array}$ & \\
\hline number of diagnosed NCDs $(0,1,2,3,4+)$ & & $\begin{array}{l}\text { There are } 9 \text { NCDs in this study: } \\
\text { hypertension, angina, arthritis, asthma, } \\
\text { CLD, diabetes, cataract, stroke, and } \\
\text { depression }\end{array}$ \\
\hline $\begin{array}{l}\text { Predicting Variables } \\
\text { 1. Multimorbidity: } \\
\text { number of diagnosed comorbidities }(0,1,2, \\
3,4+)\end{array}$ & $\begin{array}{l}\text { Outcome Variables } \\
\text { 2a. Odds of being untreated in the last } 2 \text { weeks } \\
2 b \text {. Odds of being untreated in the last } 12 \text { months } \\
\text { 3a. Odds of being uncontrolled (when treated in } \\
\text { the last } 2 \text { weeks) } \\
3 \text { b. Odds of being uncontrolled (when treated in } \\
\text { the last } 2 \text { weeks) }\end{array}$ & $\begin{array}{l}\text { All } 9 \text { NCDs can be studied for the outcome } \\
\text { on being untreated. } \\
\\
\text { The survey had symptom-based } \\
\text { assessment or physical measurements for } \\
\text { only } 6 \text { of } 9 \text { NCDs. Only these } 6 \text { NCDs could } \\
\text { be assessed in this study for being } \\
\text { undiagnosed, and for being uncontrolled. } \\
\text { These were hypertension, angina, arthritis, } \\
\text { asthma, CLD, and depression. }\end{array}$ \\
\hline $\begin{array}{l}\quad \text { Predicting Variables } \\
\text { 2. Type of comorbidity } \\
>\text { Comorbidity with only concordant NCDs } \\
\text { versus } \\
\text { comorbidity with only discordant NCDs, versus } \\
\text { comorbidity with only depression }\end{array}$ & $\begin{array}{l}\text { Outcome Variables } \\
\text { 1. Odds of being undiagnosed } \\
\text { 2a. Odds of being untreated in the last } 2 \text { weeks } \\
\text { 2b. Odds of being untreated in the last } 12 \text { months } \\
\text { 3a. Odds of being uncontrolled (when treated in } \\
\text { the last } 2 \text { weeks) } \\
3 \text { b. Odds of being uncontrolled (when treated in } \\
\text { the last } 2 \text { weeks }\end{array}$ & \\
\hline
\end{tabular}
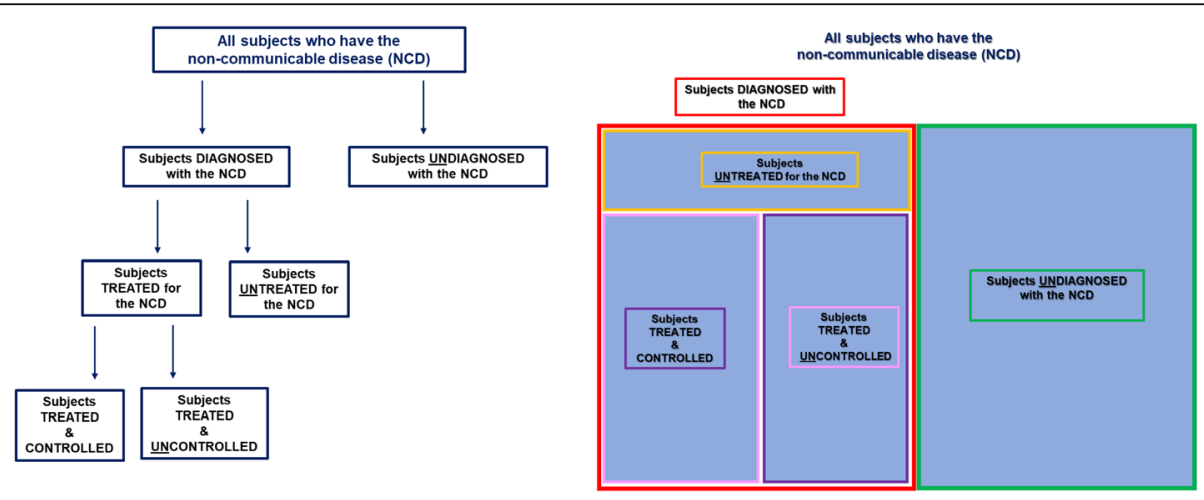

Fig. 5 Classification of subjects who are undiagnosed, untreated, and uncontrolled 
a. Adjusted odds ratios of being untreated in the last 2 weeks (unT-last 2 weeks) for each non-communicable disease (NCD), with increasing comorbidity

${ }^{+}$Multivariable logistic regression adjusted for age, sex, marital status, education level, income level, residence, insurance, and country fixed effects

Note: Cataract was only assessed for being untreated in the last 5 years (see Figure 3a)

Reference group: 0 comorbidities

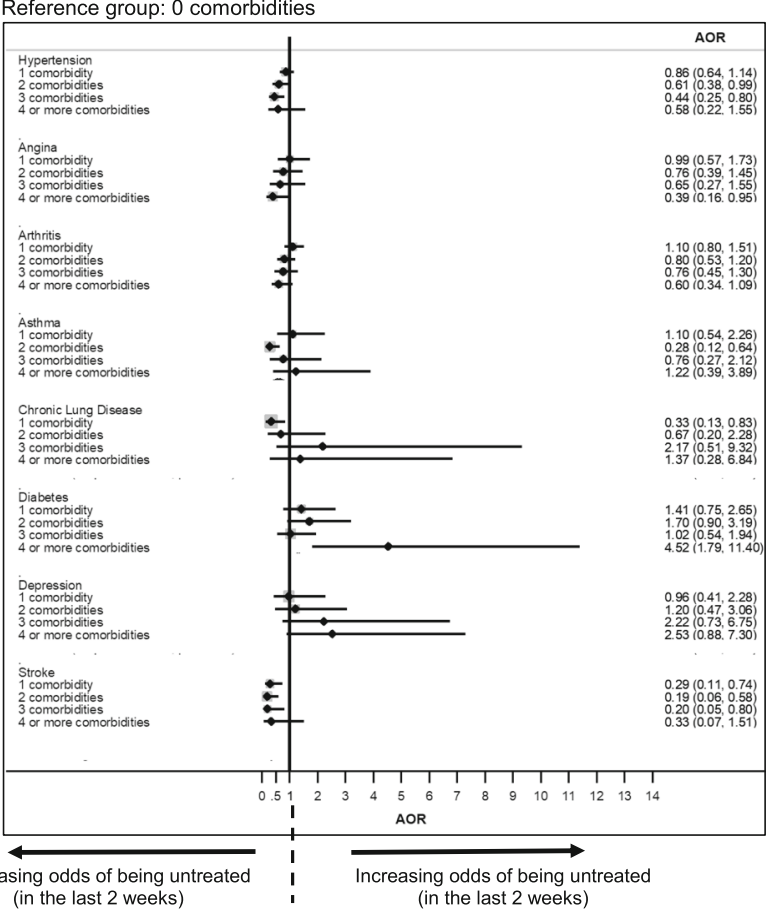

b. Odds of being untreated in the last 2 weeks (unT-last 2weeks) for each non-communicable disease (NCD), with only concordant NCDs, only discordant NCDs, and only depression

${ }^{+}$Multivariable logistic regression adjusted for age, sex, marital status, education level, income level, residence, insurance, and country fixed effects

${ }^{\wedge}$ Concordant NCDs: (a) hypertension, angina, diabetes, stroke; (b) diabetes, cataract; (c) asthma, chronic lung disease.

Note: Cataract was only assessed for being untreated in the last 5 years (see Figure $3 \mathrm{~b}$ )

Reference group: concordant NCDs and/or discordant NCDs and/or depression

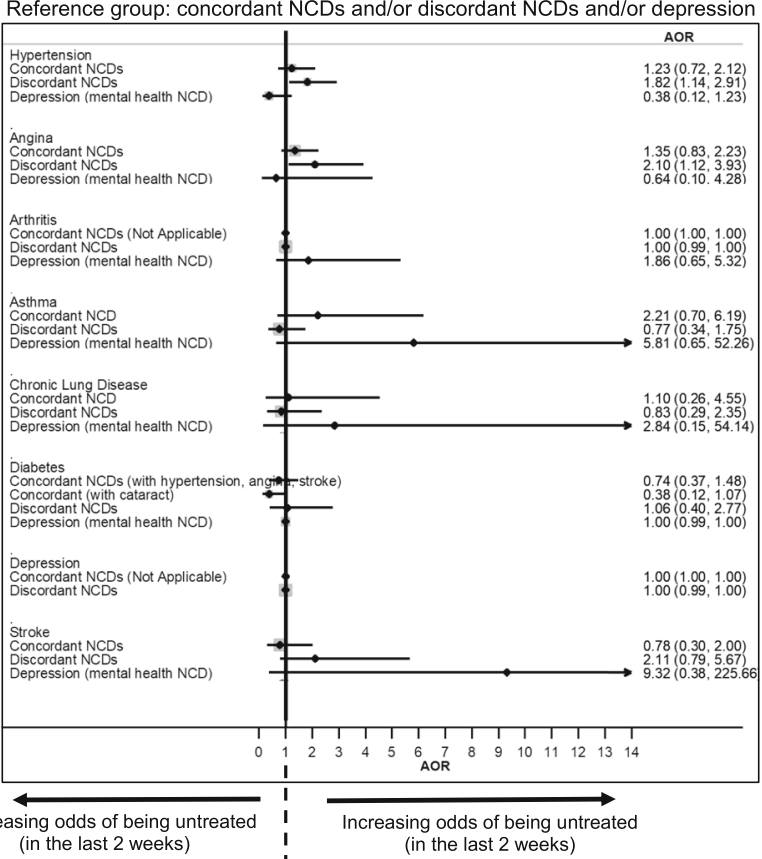

(in the last 2 weeks)

(in the last 2 weeks)

Fig. 6 (See legend on next page.) 
(See figure on previous page.)

Fig. 6 a Adjusted odds ratios of being untreated in the last 2 weeks (unT-last 2weeks) for each non-communicable disease (NCD), with increasing comorbidity. +Multivariable logistic regression adjusted for age, sex, marital status, education level, income level, residence, insurance, and country fixed effects. Note: Cataract was only assessed for being untreated in the last 5 years (see Figure 6a). b Odds of being untreated in the last 2 weeks (unT-last 2weeks) for each non-communicable disease (NCD), with only concordant NCDs, only discordant NCDs, and only depression. +Multivariable logistic regression adjusted for age, sex, marital status, education level, income level, residence, insurance, and country fixed effects. $\wedge$ Concordant NCDs: (a) hypertension, angina, diabetes, stroke; (b) diabetes, cataract; (c) asthma, chronic lung disease. Note: Cataract was only assessed for being untreated in the last 5 years (see Figure $6 b$ ) 
a. Odds of being uncontrolled (unC-T-last 2weeks) for each non-communicable disease (NCD), with increasing comorbidity

${ }^{+}$Multivariable logistic regression adjusted for age, sex, marital status, education level, income level, residence, insurance, and country fixed effects

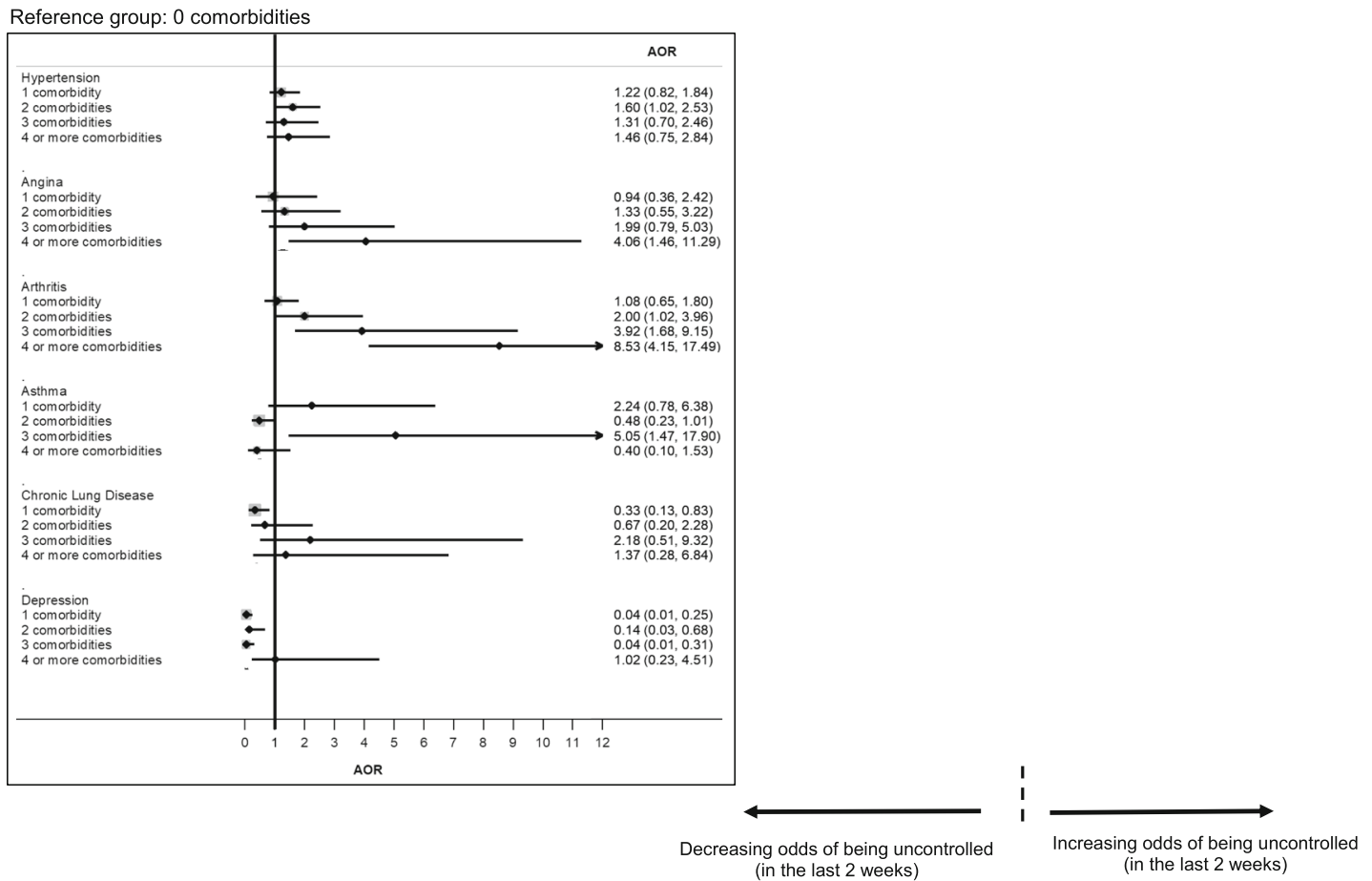

b. Odds of being uncontrolled (unC-T-last 2weeks) for each non-communicable disease (NCD), with only concordant NCDs, only discordant NCDs, and only depression

${ }^{+}$Multivariable logistic regression adjusted for age, sex, marital status, education level, income level, residence, insurance, and country fixed effects

${ }^{\wedge}$ Concordant NCDs: (a) hypertension, angina, diabetes, stroke; (b) diabetes, cataract; (c) asthma, chronic lung disease.

Reference group: concordant NCDs and/or discordant NCDs and/or depression

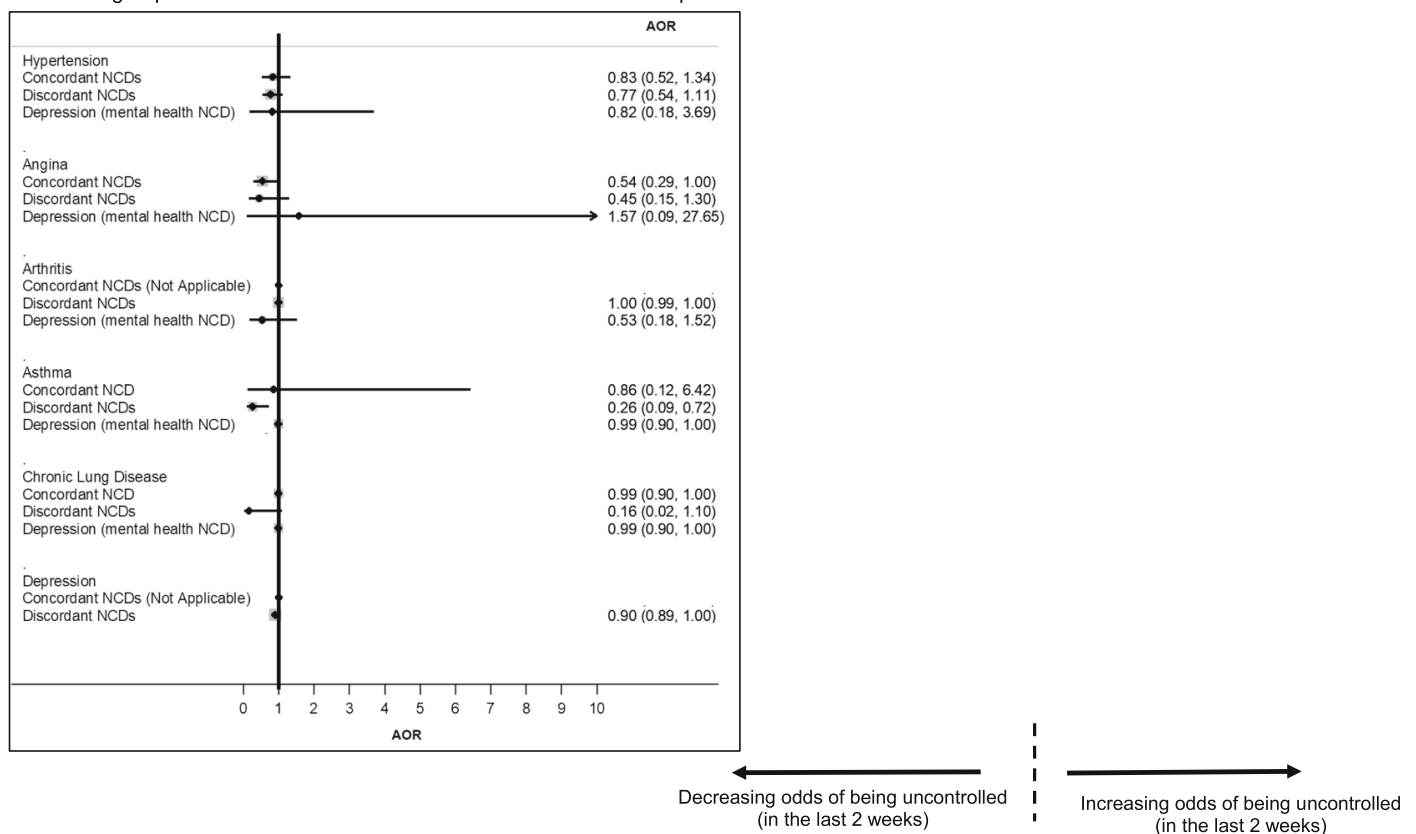

Fig. 7 (See legend on next page.) 
(See figure on previous page.)

Fig. 7 a Odds of being uncontrolled (unC-T-last 2weeks) for each non-communicable disease (NCD), with increasing comorbidity. +Multivariable logistic regression adjusted for age, sex, marital status, education level, income level, residence, insurance, and country fixed effects. b Odds of being uncontrolled (unC-T-last 2weeks) for each non-communicable disease (NCD), with only concordant NCDs, only discordant NCDs, and only depression. +Multivariable logistic regression adjusted for age, sex, marital status, education level, income level, residence, insurance, and country fixed effects. ^ Concordant NCDs: (a) hypertension, angina, diabetes, stroke; (b) diabetes, cataract; (c) asthma, chronic lung disease 
Table 3 Algorithms used to ascertain presence of non-communicable diseases

\begin{tabular}{|c|c|c|c|}
\hline NCDs & Self-reported diagnosis & $\begin{array}{l}\text { Physical measurement/Symptom-based } \\
\text { assessment }\end{array}$ & $\begin{array}{l}\text { Algorithm for physical } \\
\text { measurement/symptom-based } \\
\text { assessment }\end{array}$ \\
\hline Hypertension & $\begin{array}{l}\text { Have you ever been diagnosed with high } \\
\text { blood pressure? }\end{array}$ & $\begin{array}{l}\text { Take average of three blood pressure readings. } \\
\text { High blood pressure is defined as systolic blood } \\
\text { pressure } \geq 140 \mathrm{mmHg} \text { and diastolic blood pressure } \\
\geq 90 \mathrm{mmHg} \text {. }\end{array}$ & $\begin{array}{l}\text { High blood pressure is defined as } \\
\text { systolic blood pressure } \geq 140 \mathrm{mmHg} \\
\text { and diastolic blood pressure } \\
\geq 90 \mathrm{mmHg} \text {. }\end{array}$ \\
\hline Stroke & $\begin{array}{l}\text { Have you ever been told by a health } \\
\text { professional that you have had a stroke }\end{array}$ & No symptom-based assessment & No symptom-based assessment \\
\hline Diabetes & $\begin{array}{l}\text { Have you ever been diagnosed with } \\
\text { diabetes? }\end{array}$ & No symptom-based assessment & No symptom-based assessment \\
\hline Cataract & $\begin{array}{l}\text { In the last } 5 \text { years, were you diagnosed } \\
\text { with a cataract in one or both of your eyes? }\end{array}$ & No symptom-based assessment & No symptom-based assessment \\
\hline Arthritis & $\begin{array}{l}\text { Have you ever been diagnosed with/told } \\
\text { you have arthritis (a disease of the joints, or } \\
\text { by other names rheumatism or } \\
\text { osteoarthritis)? }\end{array}$ & $\begin{array}{l}\text { Qn 1: During the last } 12 \text { months, have you } \\
\text { experienced pain, aching, stiffness or swelling in } \\
\text { or around the joints (like arms, hands, legs or } \\
\text { feet) which were not related to an injury and } \\
\text { lasted for more than a month? } \\
\text { a. Yes } \\
\text { b. No } \\
\text { Qn 2: During the last } 12 \text { months, have you } \\
\text { experienced stiffness in the joint in the morning } \\
\text { after getting up from bed, or after a long rest of } \\
\text { the joint without movement? } \\
\text { a. Yes } \\
\text { b. No } \\
\text { Qn 3: How long did the stiffness last? } \\
\text { a. about } 30 \text { mins or less } \\
\text { b. more than } 30 \text { mins } \\
\text { Qn } 4 \text { : Did this stiffness go away after exercise or } \\
\text { movement in the joint? } \\
\text { a. Yes } \\
\text { b. No }\end{array}$ & $\begin{array}{l}\text { Arthritis= } \\
\text { Option 'a' to both question } 1 \text { and } \\
\text { question } 2 \text {. } \\
\text { OR } \\
\text { Option 'a' to both question } 3 \text { and } \\
\text { question } 4 \text {. }\end{array}$ \\
\hline Angina & $\begin{array}{l}\text { Have you ever been diagnosed with angina } \\
\text { or angina pectoris? }\end{array}$ & $\begin{array}{l}\text { Qn 1: During the last } 12 \text { months, have you } \\
\text { experienced any pain or discomfort in your chest } \\
\text { when you walk uphill or hurry? } \\
\text { a. Yes } \\
\text { b. No } \\
\text { Qn 2: During the last } 12 \text { months, have you } \\
\text { experienced any pain or discomfort in your chest } \\
\text { when you walk at an ordinary pace on level } \\
\text { ground? } \\
\text { a. Yes } \\
\text { b. No } \\
\text { Qn 3: What do you do if you get the pain or } \\
\text { discomfort when you are walking? } \\
\text { a. stop or slow down } \\
\text { b. carry on after taking a pain-relieving medicine } \\
\text { that dissolves in your mouth } \\
\text { c. carry on walking } \\
\text { Qn 4: If you stand still, what happens to the pain } \\
\text { or discomfort? } \\
\text { a. relieved } \\
\text { b. not relieved } \\
\text { Qn 5: Will you show me where you usually } \\
\text { experience the pain or discomfort? } \\
\text { a. (6 \& 11), or (7 \& 8). }\end{array}$ & $\begin{array}{l}\text { Angina= } \\
\text { Option 'a' for question } 1 \\
\text { OR } \\
\text { Option 'a' for question } 2 \\
\text { OR } \\
\text { Option 'a' for both question } 3 \text { and } \\
\text { question } 4 \text {. } \\
\text { OR } \\
\text { Option 'a' for question } 5\end{array}$ \\
\hline Asthma & $\begin{array}{l}\text { Have you ever been diagnosed with } \\
\text { asthma? }\end{array}$ & $\begin{array}{l}\text { Qn 1: Attacks of wheezing or whistling } \\
\text { breathing? } \\
\text { a. Yes } \\
\text { b. No } \\
\text { Qn 2: Attack of wheezing that came on after you } \\
\text { stopped exercising or some other physical } \\
\text { activity? } \\
\text { a. Yes } \\
\text { b. No }\end{array}$ & $\begin{array}{l}\text { Asthma= } \\
\text { Option 'a' for Qn } 1 \\
\text { OR } \\
\text { Option 'a' for all questions from } \\
\text { question } 2 \text { to question } 5 .\end{array}$ \\
\hline
\end{tabular}


Table 3 Algorithms used to ascertain presence of non-communicable diseases (Continued)

\begin{tabular}{|c|c|c|}
\hline NCDs & Self-reported diagnosis & $\begin{array}{l}\text { Physical measurement/Symptom-based } \\
\text { assessment }\end{array}$ \\
\hline & & $\begin{array}{l}\text { Qn 3: A feeling of tightness in your chest? } \\
\text { a. Yes } \\
\text { b. No } \\
\text { Qn 4: Have you woken up with a feeling of } \\
\text { tightness in your chest in the morning or any } \\
\text { other time? } \\
\text { a. Yes } \\
\text { b. No } \\
\text { Qn 5: Have you had an attack of shortness of } \\
\text { breath that came on without obvious cause } \\
\text { when you were not exercising or doing some } \\
\text { physical work? } \\
\text { a. Yes } \\
\text { b. No }\end{array}$ \\
\hline $\begin{array}{l}\text { Chronic lung } \\
\text { disease }\end{array}$ & $\begin{array}{l}\text { Have you ever been diagnosed with } \\
\text { chronic lung disease (emphysema, } \\
\text { bronchitis, COPD)? }\end{array}$ & $\begin{array}{l}\text { Qn 1: During the last } 12 \text { months, have you } \\
\text { experienced any shortness of breath at rest? } \\
\text { (while awake) } \\
\text { a. Yes } \\
\text { b. No } \\
\text { Qn 2: During the last } 12 \text { months, have you } \\
\text { experienced any coughing or wheezing for ten } \\
\text { minutes or more at a time? } \\
\text { a. Yes } \\
\text { b. No } \\
\text { Qn 3: During the last } 12 \text { months, have you } \\
\text { experienced any coughing up sputum or phlegm } \\
\text { for most days of the month for at least } 3 \\
\text { months? } \\
\text { a. Yes } \\
\text { b. No }\end{array}$ \\
\hline
\end{tabular}

Depression Have you ever been diagnosed with depression?
Algorithm for physical

measurement/symptom-based assessment

Chronic lung disease $=$ Option 'a' for Qn 1 $\mathrm{OR}$

Option 'a' for both question 2 and question 3

Qn 1: During the last 12 months, have you had a period lasting several days when you felt sad, empty or depressed?

a. Yes

b. No

Qn 2: During the last 12 months, have you had a period lasting several days when you lost interest Group B:

in most things you usually enjoy such as personal Score=1 if option 'a' to either relationships, work or hobbies/recreation?

a. Yes

b. No

Qn 3: During the last 12 months, have you had a period lasting several days when you have been feeling your energy decreased or that you are tired all the time?

a. Yes

b. No

Qn 4: Was this period [of sadness/loss of interest/ low energy] for more than 2 weeks?

a. Yes

b. No

Qn 5: Was this period [of sadness/loss of interest/ low energy] most of the day, nearly every day?

a. Yes

b. No

Qn 6: During this period, did you lose your appetite?

a. Yes

b. No

Group A:

Score=1 if option 'a' to question 1 Score $=1$ if option 'a' question 2

Score $=1$ if option 'a' to question 3 Addition of score $=$ score for Group question 8 or question 9 Score $=1$ if option ' $a$ ' to either question 7 or question 10 Score $=1$ if option ' $a$ ' to either question 11 or question 13 Score $=1$ if option ' $a$ ' to either question 14 or question 15 Score $=1$ if option ' $a$ ' to either question 17 or question 18 Addition of score= score for Group Group C: Score $=1$ if option 'a' to question 6 Group D:

Score $=1$ if option ' $a$ ' to question 12 Group E:

Score for Group B + Score for Group C + Score for Group D Group F:

Score=1 if option 'a' to question 4 Group G:

Qn 7: Did you notice any slowing down in your thinking?

a. Yes

b. No

On 8: Did you notice any problems falling asleep?

a. Yes for Group $F$ is $=1$, add the score for Score for Group A + Score for Group E

Depression=

Score for Group $\mathrm{G} \geq 4$
If Score for Group A $\geq 2$, AND Score 
Table 3 Algorithms used to ascertain presence of non-communicable diseases (Continued)

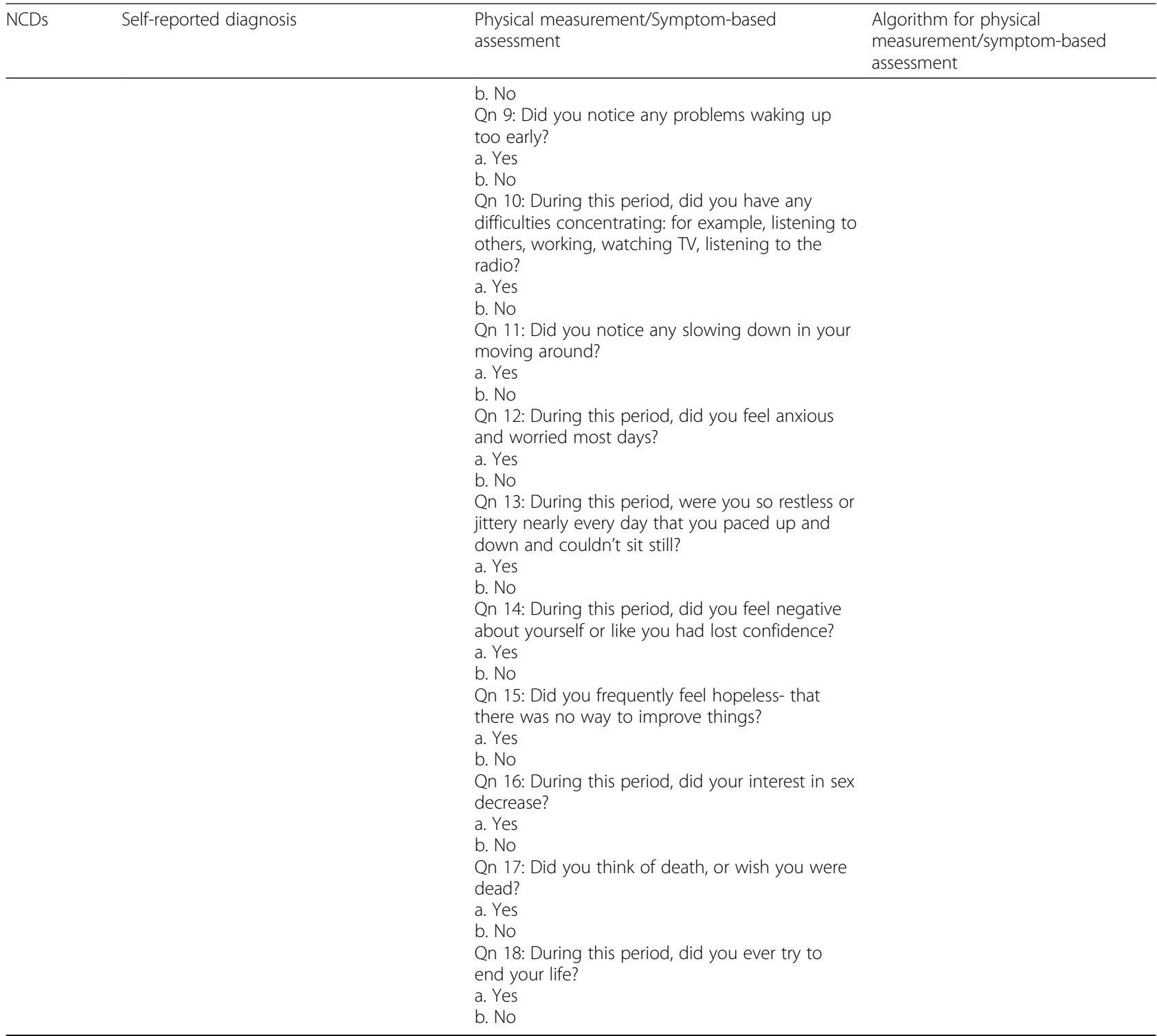


Table 4 Definitions of prevalence of each chronic condition being undiagnosed, untreated, and uncontrolled

\begin{tabular}{|c|c|c|c|c|c|}
\hline \multirow{3}{*}{$\begin{array}{l}\text { Non- } \\
\text { communicable } \\
\text { disease }\end{array}$} & \multicolumn{5}{|l|}{ Prevalence } \\
\hline & \multirow[t]{2}{*}{ Undiagnosed $^{a}$} & \multicolumn{2}{|l|}{ Untreated } & \multicolumn{2}{|l|}{ Uncontrolled } \\
\hline & & $\begin{array}{l}\text { unT-last } 2 \text { weeks } \\
\text { (untreated in the last } 2 \\
\text { weeks) }\end{array}$ & $\begin{array}{l}\text { unT-last } 12 \text { months } \\
\text { (untreated in last } 12 \\
\text { months) }\end{array}$ & $\begin{array}{l}\text { unC-T-last } 2 \text { weeks }^{\text {b }} \\
\text { (treated in the last } 2 \\
\text { weeks, and uncontrolled) }\end{array}$ & $\begin{array}{l}\text { unC-T-last } 12 \text { months }^{\mathrm{b}} \\
\text { (treated in the last } 12 \\
\text { months, and } \\
\text { uncontrolled) }\end{array}$ \\
\hline Hypertension & $\begin{array}{l}\text { All subjects who self- } \\
\text { reported not being } \\
\text { diagnosed with } \\
\text { hypertension, but have } \\
\text { hypertension based on } \\
\text { symptom-based } \\
\text { assessment. }\end{array}$ & $\begin{array}{l}\text { All subjects who self- } \\
\text { reported being diag- } \\
\text { nosed with hyperten- } \\
\text { sion, but self-reported } \\
\text { not taking treatment in } \\
\text { the last } 2 \text { weeks. } \\
\text { Treatment that they self- } \\
\text { reported taking include } \\
\text { medications or other } \\
\text { treatment such as a } \\
\text { weight loss program or } \\
\text { changing eating habits. }\end{array}$ & $\begin{array}{l}\text { All subjects who self- } \\
\text { reported being diag- } \\
\text { nosed with hyperten- } \\
\text { sion, but self-reported } \\
\text { not taking treatment in } \\
\text { the last } 12 \text { months. } \\
\text { Treatment that they } \\
\text { self-reported taking in- } \\
\text { clude medications or } \\
\text { other treatment such as } \\
\text { a weight loss program } \\
\text { or changing eating } \\
\text { habits. }\end{array}$ & $\begin{array}{l}\text { All subjects who are self- } \\
\text { reported taking treat- } \\
\text { ment for hypertension in } \\
\text { the last } 2 \text { weeks, but } \\
\text { have hypertension based } \\
\text { on BP measurement. }\end{array}$ & $\begin{array}{l}\text { All subjects who are } \\
\text { self-reported taking } \\
\text { treatment for hyperten- } \\
\text { sion in the last } 12 \\
\text { months, but have hyper- } \\
\text { tension based on BP } \\
\text { measurement }\end{array}$ \\
\hline Angina & $\begin{array}{l}\text { All subjects who self- } \\
\text { reported not being } \\
\text { diagnosed with angina, } \\
\text { but have angina based } \\
\text { on symptom-based } \\
\text { assessment. }\end{array}$ & $\begin{array}{l}\text { All subjects who self- } \\
\text { reported being diag- } \\
\text { nosed with angina, but } \\
\text { self-reported not taking } \\
\text { treated in the last } 2 \\
\text { weeks. } \\
\text { Treatment that they self- } \\
\text { reported taking include } \\
\text { medications or other } \\
\text { treatment. }\end{array}$ & $\begin{array}{l}\text { All subjects who self- } \\
\text { reported being diag- } \\
\text { nosed with angina, but } \\
\text { self-reported not taking } \\
\text { treatment in the last } 12 \\
\text { months. } \\
\text { Treatment that they } \\
\text { self-reported taking in- } \\
\text { clude medications or } \\
\text { other treatment. }\end{array}$ & $\begin{array}{l}\text { All subjects who self- } \\
\text { reported taking treat- } \\
\text { ment for angina in the } \\
\text { last } 2 \text { weeks, but have } \\
\text { angina based on } \\
\text { symptom-based } \\
\text { assessment. }\end{array}$ & $\begin{array}{l}\text { All subjects who self- } \\
\text { reported taking treat- } \\
\text { ment for angina in the } \\
\text { last } 12 \text { months, but have } \\
\text { angina based on } \\
\text { symptom-based } \\
\text { assessment. }\end{array}$ \\
\hline Arthritis & $\begin{array}{l}\text { All subjects who self- } \\
\text { reported not being } \\
\text { diagnosed with arthritis, } \\
\text { but have arthritis based } \\
\text { on symptom-based } \\
\text { assessment. }\end{array}$ & $\begin{array}{l}\text { All subjects who self- } \\
\text { reported being diag- } \\
\text { nosed with arthritis, but } \\
\text { self-reported not taking } \\
\text { treatment in the last } 2 \\
\text { weeks. } \\
\text { Treatment that they self- }\end{array}$ & $\begin{array}{l}\text { All subjects who self- } \\
\text { reported being diag- } \\
\text { nosed with arthritis, but } \\
\text { self-reported not taking } \\
\text { treatment in the last } 12 \\
\text { months. } \\
\text { Treatment that they }\end{array}$ & $\begin{array}{l}\text { All subjects who self- } \\
\text { reported taking treat- } \\
\text { ment for arthritis in the } \\
\text { last } 2 \text { weeks, but have } \\
\text { arthritis based on } \\
\text { symptom-based } \\
\text { assessment. }\end{array}$ & $\begin{array}{l}\text { All subjects who self- } \\
\text { reported taking treat- } \\
\text { ment for arthritis in the } \\
\text { last } 12 \text { months, but have } \\
\text { arthritis based on } \\
\text { symptom-based } \\
\text { assessment. }\end{array}$ \\
\hline
\end{tabular}

Asthma $\quad$ All subjects who selfreported not being diagnosed with asthma, but have asthma based on symptom-based assessment.

$\begin{array}{ll}\text { Chronic Lung } & \text { All subjects who self- } \\ \text { Disease } & \text { reported not being } \\ & \text { diagnosed with chronic } \\ & \text { lung disease, but have } \\ \text { chronic lung disease } & \text { based on symptom- } \\ & \text { based assessment. }\end{array}$

Diabetes $\quad$ Not applicable (Diabetes has no symptom-based assessment)

\section{medications or other treatment.}

All subjects who selfreported being diagnosed with asthma, but self-reported not taking treatment in the last 2 weeks.

Treatment that they selfreported taking include medications or other treatment.

All subjects who selfreported being diagnosed with chronic lung disease, but selfreported not taking treatment in the last 2 weeks.

Treatment that they selfreported taking include medications or other treatment (like oxygen).

All subjects who selfreported being diagnosed with diabetes, but self-reported not taking self-reported taking include medications or other treatment.

All subjects who selfreported being diagnosed with asthma, but self-reported not taking treatment in the last 12 months.

Treatment that they self-reported taking include medications or other treatment.

All subjects who selfreported being diag-

nosed with chronic lung disease, but selfreported not taking treatment in the last 12 months.

- Treatment that they self-reported taking include medications or other treatment (like oxygen).

All subjects who selfreported being diagnosed with diabetes, but self-reported not
All subjects who selfreported taking treatment for asthma in the last 2 weeks, but have asthma based on symptom-based assessment.

All subjects who selfreported taking treatment for chronic lung disease in the last 2 weeks, but have chronic lung disease based on symptom-based assessment.
All subjects who selfreported taking treatment for asthma in the last 12 months, but have asthma based on symptom-based assessment.

All subjects who selfreported taking treatment for chronic lung disease in the last 12 months, but have chronic lung disease based on symptombased assessment.
Not applicable (Diabetes has no symptom-based assessment)
Not applicable (Diabetes has no symptom-based assessment) 
Table 4 Definitions of prevalence of each chronic condition being undiagnosed, untreated, and uncontrolled (Continued)

\begin{tabular}{|c|c|c|c|c|c|}
\hline \multirow{3}{*}{$\begin{array}{l}\text { Non- } \\
\text { communicable } \\
\text { disease }\end{array}$} & \multicolumn{5}{|l|}{ Prevalence } \\
\hline & \multirow[t]{2}{*}{ Undiagnosed $^{\mathrm{a}}$} & \multicolumn{2}{|l|}{ Untreated } & \multicolumn{2}{|l|}{ Uncontrolled } \\
\hline & & $\begin{array}{l}\text { unT-last } 2 \text { weeks } \\
\text { (untreated in the last } 2 \\
\text { weeks) }\end{array}$ & $\begin{array}{l}\text { unT-last } 12 \text { months } \\
\text { (untreated in last } 12 \\
\text { months) }\end{array}$ & $\begin{array}{l}\text { unC-T-last } 2 \text { weeks } \\
\text { (treated in the last } 2 \\
\text { weeks, and uncontrolled) }\end{array}$ & $\begin{array}{l}\text { unC-T-last } 12 \text { months }^{\mathrm{b}} \\
\text { (treated in the last } 12 \\
\text { months, and } \\
\text { uncontrolled) }\end{array}$ \\
\hline & & $\begin{array}{l}\text { treatment in the last } 2 \\
\text { weeks. } \\
\text { Treatment that they self- } \\
\text { reported taking include } \\
\text { insulin or other blood } \\
\text { sugar lowering medica- } \\
\text { tions, special diet, exer- } \\
\text { cise regime, or weight } \\
\text { control program, as rec- } \\
\text { ommended by a health } \\
\text { professional. }\end{array}$ & $\begin{array}{l}\text { taking treatment in the } \\
\text { last } 12 \text { months. } \\
\text { Treatment that they } \\
\text { self-reported taking in- } \\
\text { clude insulin or other } \\
\text { blood sugar lowering } \\
\text { medications only. }\end{array}$ & & \\
\hline Cataract & $\begin{array}{l}\text { Not applicable (Cataract } \\
\text { has no symptom-based } \\
\text { assessment) }\end{array}$ & $\begin{array}{l}\text { Not applicable (Subjects } \\
\text { self-reported not being } \\
\text { treated in the last } 5 \\
\text { years, not in the last } 2 \\
\text { weeks) }\end{array}$ & $\begin{array}{l}\text { All subjects who self- } \\
\text { reported being diag- } \\
\text { nosed with cataract, but } \\
\text { self-reported not taking } \\
\text { treatment in the last } 5 \\
\text { years. } \\
\text { Treatment refers to eye } \\
\text { surgery. }\end{array}$ & $\begin{array}{l}\text { Not applicable (Cataract } \\
\text { has no symptom-based } \\
\text { assessment) }\end{array}$ & $\begin{array}{l}\text { Not applicable (Cataract } \\
\text { has no symptom-based } \\
\text { assessment) }\end{array}$ \\
\hline Depression & $\begin{array}{l}\text { All subjects who self- } \\
\text { reported not being } \\
\text { diagnosed with } \\
\text { depression, but have } \\
\text { depression based on } \\
\text { symptom-based } \\
\text { assessment. }\end{array}$ & $\begin{array}{l}\text { All subjects who self- } \\
\text { reported being diag- } \\
\text { nosed with depression, } \\
\text { but self-reported not } \\
\text { taking treatment in the } \\
\text { last } 2 \text { weeks. } \\
\text { Treatment that they self- } \\
\text { reported taking include } \\
\text { medications or other } \\
\text { treatment. Other treat- } \\
\text { ment can include at- } \\
\text { tending therapy or } \\
\text { counselling sessions. }\end{array}$ & $\begin{array}{l}\text { All subjects who self- } \\
\text { reported being diag- } \\
\text { nosed with depression, } \\
\text { but self-reported not } \\
\text { taking treatment in the } \\
\text { last } 12 \text { months. } \\
\text { Treatment that they } \\
\text { self-reported taking in- } \\
\text { clude medications or } \\
\text { other treatment. Other } \\
\text { treatment can include } \\
\text { attending therapy or } \\
\text { counselling sessions. }\end{array}$ & $\begin{array}{l}\text { All subjects who self- } \\
\text { reported taking treat- } \\
\text { ment for depression in } \\
\text { the last } 2 \text { weeks, but has } \\
\text { depression based on } \\
\text { symptom-based } \\
\text { assessment. }\end{array}$ & $\begin{array}{l}\text { All subjects who self- } \\
\text { reported taking treat- } \\
\text { ment for depression in } \\
\text { the last } 12 \text { months, but } \\
\text { has depression based } \\
\text { on symptom-based } \\
\text { assessment. }\end{array}$ \\
\hline Stroke & $\begin{array}{l}\text { Not applicable (Stroke } \\
\text { has no symptom-based } \\
\text { assessment) }\end{array}$ & $\begin{array}{l}\text { All subjects who self- } \\
\text { reported being diag- } \\
\text { nosed with stroke, but } \\
\text { self-reported not taking } \\
\text { treatment in the last } 2 \\
\text { weeks. } \\
\text { Treatment that they self- } \\
\text { reported taking include } \\
\text { to medications or other } \\
\text { treatment. }\end{array}$ & $\begin{array}{l}\text { All subjects who self- } \\
\text { reported being diag- } \\
\text { nosed with stroke, but } \\
\text { self-reported not taking } \\
\text { treatment in the last } 12 \\
\text { months. } \\
\text { Treatment that they } \\
\text { self-reported taking in- } \\
\text { clude medications or } \\
\text { other treatment. }\end{array}$ & $\begin{array}{l}\text { Not applicable (Stroke } \\
\text { has no symptom-based } \\
\text { assessment) }\end{array}$ & $\begin{array}{l}\text { Not applicable (Stroke } \\
\text { has no symptom-based } \\
\text { assessment) }\end{array}$ \\
\hline
\end{tabular}

a Regarding self-reporting diagnoses, we defined respondents as self-reporting a non-communicable disease if they answered affirmatively to: "Have you ever been diagnosed with...?"

${ }^{\mathrm{b}}$ All subjects who self-reported taking medication or other treatment are a perfect subset of those who self-reported being diagnosed, because the questionnaire only asks subjects if they are taking treatment, if they self-report affirmatively to being diagnosed 
Table 5 Prevalence of comorbidity for each non-communicable disease

\begin{tabular}{|c|c|c|c|c|c|c|c|c|c|c|}
\hline & & \multicolumn{9}{|c|}{ Non-communicable disease } \\
\hline & & Hypertension & Angina & Arthritis & Asthma & $\begin{array}{l}\text { Chronic Lung } \\
\text { Disease }\end{array}$ & Diabetes & Cataract & Depression & Stroke \\
\hline \multirow{5}{*}{$\begin{array}{l}\text { Prevalence of subjects } \\
\text { (\%) }\end{array}$} & No comorbidity & 38.77 & 19.59 & 44.80 & 34.11 & 34.87 & 29.25 & 32.39 & 39.68 & 22.48 \\
\hline & 1 comorbidity & 29.42 & 30.54 & 25.91 & 24.93 & 27.98 & 23.52 & 25.71 & 24.45 & 30.06 \\
\hline & 2 comorbidities & 17.21 & 24.54 & 15.83 & 15.70 & 12.46 & 18.87 & 20.14 & 20.79 & 21.04 \\
\hline & 3 comorbidities & 7.48 & 14.10 & 6.37 & 12.36 & 12.46 & 15.27 & 13.33 & 5.93 & 12.16 \\
\hline & $\begin{array}{l}4+ \\
\text { comorbidities }\end{array}$ & 7.11 & 11.23 & 7.10 & 12.89 & 12.23 & 13.10 & 8.43 & 9.15 & 14.26 \\
\hline
\end{tabular}

Table 6 Prevalence of undiagnosed subjects for each non-communicable disease, with increasing number of comorbidities

\begin{tabular}{|c|c|c|c|c|c|c|c|}
\hline & & \multicolumn{6}{|c|}{ Undiagnosed non-communicable disease } \\
\hline & & Hypertension & Angina & Arthritis & Asthma & Chronic Lung Disease & Depression \\
\hline \multirow[t]{5}{*}{ Prevalence of undiagnosed subjects (\%) } & No comorbidy & 72.25 & 78.55 & 48.67 & 55.51 & 50.82 & 71.52 \\
\hline & 1 comorbidity & 46.34 & 60.82 & 41.76 & 56.76 & 50.92 & 69.04 \\
\hline & 2 comorbidities & 30.61 & 44.95 & 33.04 & 54.28 & 55.44 & 54.98 \\
\hline & 3 comorbidities & 20.53 & 32.84 & 24.48 & 46.58 & 48.29 & 67.12 \\
\hline & $4+$ comorbidities & 16.61 & 28.63 & 21.77 & 64.09 & 36.38 & 63.45 \\
\hline
\end{tabular}

Table 7 Prevalence of undiagnosed subjects for each non-communicable disease (NCD), with diagnosed concordant NCDs only, discordant NCDs only, and depression only

\begin{tabular}{|c|c|c|c|c|c|c|c|}
\hline & & \multicolumn{6}{|c|}{ Undiagnosed non-communicable disease } \\
\hline & & Hypertension & Angina & Arthritis & Asthma & $\begin{array}{l}\text { Chronic Lung } \\
\text { Disease }\end{array}$ & Depression \\
\hline \multirow[t]{3}{*}{$\begin{array}{l}\text { Prevalence of undiagnosed } \\
\text { subjects (\%) }\end{array}$} & $\begin{array}{l}\text { Diagnosed with only concordant } \\
\text { NCDs }\end{array}$ & 26.83 & 39.20 & NA & 50.75 & 42.34 & NA \\
\hline & $\begin{array}{l}\text { Diagnosed with only discordant } \\
\text { NCDs }\end{array}$ & 34.44 & 48.74 & 35.63 & 52.05 & 48.16 & 64.92 \\
\hline & Diagnosed with only depression & 35.49 & 65.45 & 34.45 & 47.70 & 57.51 & NA \\
\hline
\end{tabular}

Table 8 Prevalence of untreated subjects for each non-communicable disease, with increasing comorbidities. (untreated in the last 2 weeks)

\begin{tabular}{|c|c|c|c|c|c|c|c|c|c|}
\hline & & \multicolumn{8}{|c|}{ Untreated non-communicable disease (in the last 2 weeks) } \\
\hline & & Hypertension & Angina & Arthritis & Asthma & $\begin{array}{l}\text { Chronic Lung } \\
\text { Disease }\end{array}$ & Diabetes & Depression & Stroke \\
\hline \multirow{5}{*}{$\begin{array}{l}\text { Prevalence of untreated subjects } \\
(\%)\end{array}$} & No comorbidity & 42.93 & 56.15 & 62.16 & 51.80 & 92.96 & 30.64 & 69.11 & 85.39 \\
\hline & 1 comorbidity & 35.72 & 49.76 & 62.20 & 54.76 & 84.84 & 32.85 & 67.67 & 55.63 \\
\hline & 2 comorbidities & 25.95 & 38.20 & 51.51 & 23.28 & 87.60 & 37.28 & 72.29 & 42.43 \\
\hline & 3 comorbidities & 20.03 & 30.81 & 48.93 & 36.61 & 94.57 & 22.65 & 78.51 & 42.16 \\
\hline & $\begin{array}{l}4+ \\
\text { comorbidities }\end{array}$ & 25.08 & 18.97 & 44.50 & 51.68 & 96.37 & 50.40 & 74.33 & 54.05 \\
\hline
\end{tabular}


Table 9 Prevalence of untreated subjects for each non-communicable disease (NCD), for comorbidity with only concordant NCDs, only discordant NCDs, and only depression. (untreated in the last 2 weeks)

\begin{tabular}{|c|c|c|c|c|c|c|c|c|c|}
\hline & & \multicolumn{8}{|c|}{ Untreated non-communicable disease (NCD) (in the last 2 weeks) } \\
\hline & & Hypertension & Angina & Arthritis & Asthma & $\begin{array}{l}\text { Chronic } \\
\text { Lung } \\
\text { Disease }\end{array}$ & Diabetes & Depression & Stroke \\
\hline \multirow[t]{3}{*}{$\begin{array}{l}\text { Prevalence of } \\
\text { untreated subjects } \\
(\%)\end{array}$} & $\begin{array}{l}\text { Comorbidity with } \\
\text { only concordant } \\
\text { NCDs }\end{array}$ & 27.39 & 40.49 & NA & 59.47 & 89.09 & $\begin{array}{l}31.46 \text { (concordant with } \\
\text { hypertension, angina, and/or } \\
\text { stroke); } \\
25.85 \text { (concordant with } \\
\text { cataract) }\end{array}$ & NA & 46.50 \\
\hline & $\begin{array}{l}\text { Comorbidity with } \\
\text { only discordant } \\
\text { NCDs }\end{array}$ & 38.51 & 59.21 & 55.34 & 40.85 & 89.76 & 37.04 & 71.34 & 67.84 \\
\hline & $\begin{array}{l}\text { Comorbidity with } \\
\text { only depression }\end{array}$ & 35.81 & 30.41 & 70.33 & 89.11 & 98.16 & 0.40 & NA & 88.85 \\
\hline
\end{tabular}

Table 10 Prevalence of untreated subjects for each non-communicable disease, with increasing comorbidity. (untreated in the last 12 months)

\begin{tabular}{|c|c|c|c|c|c|c|c|c|c|c|}
\hline & & \multicolumn{9}{|c|}{ Untreated non-communicable disease (NCD) (in the last 12 months) } \\
\hline & & Hypertension & Angina & Arthritis & Asthma & $\begin{array}{l}\text { Chronic } \\
\text { Lung } \\
\text { Disease }\end{array}$ & Diabetes & $\begin{array}{l}\text { Cataract } \\
\text { (last } 5 \\
\text { yrs) }\end{array}$ & Depression & Stroke \\
\hline \multirow[t]{3}{*}{$\begin{array}{l}\text { Prevalence } \\
\text { of untreated } \\
\text { subjects (\%) }\end{array}$} & $\begin{array}{l}\text { Comorbidity } \\
\text { with only } \\
\text { concordant } \\
\text { NCDs }\end{array}$ & 8.72 & 12.48 & NA & 43.09 & 79.17 & $\begin{array}{l}19.64 \text { (concordant with } \\
\text { hypertension, angina, and/or } \\
\text { stroke); } 23.17 \text { (concordant with } \\
\text { cataract) }\end{array}$ & 61.96 & NA & 34.78 \\
\hline & $\begin{array}{l}\text { Comorbidity } \\
\text { with only } \\
\text { discordant } \\
\text { NCDs }\end{array}$ & 19.16 & 30.68 & 28.96 & 28.98 & 84.70 & 24.81 & 65.05 & 63.81 & 63.21 \\
\hline & $\begin{array}{l}\text { Comorbidity } \\
\text { with only } \\
\text { depression }\end{array}$ & 22.76 & 17.10 & 33.84 & 4.11 & 98.16 & 65.83 & 92.27 & NA & 92.66 \\
\hline
\end{tabular}

Table 11 Prevalence of untreated subjects for each non-communicable disease (NCD), for comorbidity with only concordant NCDs, only discordant NCDs, and only depression. (untreated in the last 12 months)

\begin{tabular}{|c|c|c|c|c|c|c|c|c|c|c|}
\hline & & \multicolumn{9}{|c|}{ Untreated non-communicable disease (NCD) (in the last 12 months) } \\
\hline & & Hypertension & Angina & Arthritis & Asthma & $\begin{array}{l}\text { Chronic Lung } \\
\text { Disease }\end{array}$ & Diabetes & Cataract & Depression & Stroke \\
\hline \multirow{5}{*}{$\begin{array}{l}\text { Prevalence of untreated } \\
\text { subjects (\%) }\end{array}$} & 0 comorbidity & 25.02 & 33.34 & 35.15 & 20.07 & 84.14 & 24.82 & 55.71 & 63.12 & 81.46 \\
\hline & 1 comorbidity & 16.19 & 18.49 & 31.88 & 33.20 & 78.11 & 21.84 & 62.71 & 72.19 & 48.85 \\
\hline & $\begin{array}{l}2 \\
\text { comorbidities }\end{array}$ & 10.94 & 14.45 & 28.91 & 20.02 & 82.69 & 29.41 & 62.43 & 59.68 & 28.21 \\
\hline & $\begin{array}{l}3 \\
\text { comorbidities }\end{array}$ & 8.67 & 11.64 & 28.02 & 29.22 & 90.08 & 13.12 & 50.26 & 52.32 & 8.14 \\
\hline & $\begin{array}{l}4+ \\
\text { comorbidities }\end{array}$ & 6.28 & 6.75 & 19.31 & $22 . .39$ & 94.34 & 34.80 & 77.69 & 58.37 & 17.85 \\
\hline
\end{tabular}


Table 12 Prevalence of uncontrolled subjects for each non-communicable disease, with increasing comorbidity. (treated in the last 2 weeks)

\begin{tabular}{|c|c|c|c|c|c|c|c|}
\hline & & \multicolumn{6}{|c|}{ Uncontrolled non-communicable disease (NCD) (treated in the last 2 weeks) } \\
\hline & & Hypertension & Angina & Arthritis & Asthma & Chronic Lung Disease & Depression \\
\hline \multirow{5}{*}{$\begin{array}{l}\text { Prevalence of uncontrolled } \\
\text { subjects (\%) }\end{array}$} & 0 comorbidity & 65.41 & 78.87 & 70.99 & 82.22 & 74.00 & 68.94 \\
\hline & 1 comorbidity & 70.45 & 76.22 & 71.85 & 86.14 & 92.13 & 14.40 \\
\hline & 2 comorbidities & 76.95 & 83.27 & 83.68 & 60.91 & 80.63 & 49.12 \\
\hline & 3 comorbidities & 75.60 & 89.95 & 90.27 & 95.53 & 93.60 & 44.55 \\
\hline & 4+ comorbidities & 78.46 & 94.32 & 95.99 & 63.17 & 50.84 & 79.57 \\
\hline
\end{tabular}

Table 13 Prevalence of uncontrolled subjects for each non-communicable disease (NCD), for comorbidity with only concordant NCDs, only discordant NCDs, and only depression. (treated in the last 2 weeks)

\begin{tabular}{|c|c|c|c|c|c|c|c|}
\hline & & \multicolumn{6}{|c|}{$\begin{array}{l}\text { Uncontrolled non-communicable disease (NCD) (treated in the last } 2 \\
\text { weeks) }\end{array}$} \\
\hline & & Hypertension & Angina & Arthritis & Asthma & $\begin{array}{l}\text { Chronic Lung } \\
\text { Disease }\end{array}$ & Depression \\
\hline \multirow[t]{3}{*}{$\begin{array}{l}\text { Prevalence of uncontrolled } \\
\text { subjects (\%) }\end{array}$} & $\begin{array}{l}\text { Comorbidity with only concordant } \\
\text { NCDs }\end{array}$ & 73.49 & 80.28 & NA & 84.71 & 99.99 & NA \\
\hline & $\begin{array}{l}\text { Comorbidity with only discordant } \\
\text { NCDs }\end{array}$ & 70.43 & 75.87 & 81.81 & 66.33 & 81.08 & 36.99 \\
\hline & Comorbidity with only depression & 60.62 & 86.99 & 82.31 & 99.96 & 99.99 & NA \\
\hline
\end{tabular}

Table 14 Prevalence of uncontrolled subjects for each non-communicable disease, with increasing comorbidity (treated in last 12 months)

\begin{tabular}{|c|c|c|c|c|c|c|c|}
\hline & & \multicolumn{6}{|c|}{ Uncontrolled non-communicable disease (NCD) (treated in the last 12 months) } \\
\hline & & Hypertension & Angina & Arthritis & Asthma & Chronic Lung Disease & Depression \\
\hline \multirow[t]{5}{*}{ Prevalence of uncontrolled subjects (\%) } & 0 comorbidity & 63.43 & 73.09 & 66.56 & 78.30 & 60.50 & 68.83 \\
\hline & 1 comorbidity & 64.21 & 72.46 & 69.86 & 73.17 & 89.96 & 40.21 \\
\hline & 2 comorbidities & 74.70 & 77.12 & 83.94 & 65.36 & 54.62 & 66.71 \\
\hline & 3 comorbidities & 72.32 & 83.29 & 85.92 & 93.47 & 82.47 & 46.76 \\
\hline & $4+$ comorbidities & 67.49 & 90.97 & 81.42 & 86.88 & 52.97 & 77.41 \\
\hline
\end{tabular}

Table 15 Prevalence of uncontrolled subjects for each non-communicable disease (NCD), for comorbidity with only concordant NCDs, discordant NCDs, and depression. (treated in the last 12 months)

\begin{tabular}{|c|c|c|c|c|c|c|c|}
\hline & & \multicolumn{6}{|c|}{ Uncontrolled non-communicable disease (NCD) (in last 12 months) } \\
\hline & & Hypertension & Angina & Arthritis & Asthma & $\begin{array}{l}\text { Chronic Lung } \\
\text { Disease }\end{array}$ & Depression \\
\hline \multirow[t]{3}{*}{$\begin{array}{l}\text { Prevalence of uncontrolled } \\
\text { subjects (\%) }\end{array}$} & $\begin{array}{l}\text { Comorbidity with only concordant } \\
\text { NCDs }\end{array}$ & 63.43 & 84.36 & NA & 86.93 & 84.48 & NA \\
\hline & $\begin{array}{l}\text { Comorbidity with only discordant } \\
\text { NCDs }\end{array}$ & 67.35 & 63.19 & 77.46 & 65.13 & 72.96 & 57.77 \\
\hline & Comorbidity with only depression & 52.27 & 88.30 & 63.19 & 62.69 & 99.99 & NA \\
\hline
\end{tabular}




\section{Abbreviations}

AOR: Adjusted odds ratio; CLD: Chronic lung disease; MICs: Middle-income countries; NCD: Non-communicable disease;; WHO SAGE: World Health Organisation Study of Global Ageing and Adult Health

\section{Acknowledgements}

The abstract of this manuscript was presented at the European Public Health Conference 2019 (G Sum, G C H Koh, S W Mercer, Y W Lim, A Majeed, B Oldenburg, J T Lee, Patients with more comorbidities have better detection but poorer management of chronic diseases, European Journal of Public Health, Volume 29, Issue Supplement_4, November 2019, ckz185.030, https:// doi.org/10.1093/eurpub/ckz185.030)

\section{Authors' contributions}

SG and LJT contributed to the conception and design of this research. SG conducted the data analyses and interpreted the data. SG wrote the first, second, and subsequent drafts of the paper. All authors contributed to the interpretation of findings and substantially revised the manuscript for important intellectual content. All authors read and approved the final manuscript.

\section{Funding}

Sum G was funded by the President's Graduate Fellowship, National University of Singapore. Lee JT was supported by the Ministry of Education Singapore, Tier 1 grant (R-608-000-162-114). Koh G was supported by the Singapore Ministry of Health's National Medical Research Council under the Centre Grant Programme- Singapore Population Health Improvement Centre (NMRC/CG/C026/2017_NUHS). Each funding body played a role in funding the analysis and interpretation of data, and writing of the manuscript

\section{Availability of data and materials}

No additional data available.

\section{Ethics approval and consent to participate}

The National University of Singapore Institutional Review Board (NUS IRB) approved the secondary data analysis of WHO SAGE Wave 1. The WHO SAGE study received human subjects testing and ethics council approval from research review boards local to each participating site, and from the WHO Ethical Review Committee. Written informed consent was obtained by WHO SAGE from each respondent before interview and examination. The list of institutions involved in each country is listed below:

Ghana: Department of Community Health, University of Ghana Medical School; Department of Community Health, University of Ghana Medical School.

China: National Center for Chronic and Noncommunicable Disease Control and Prevention, China Center for Disease Control and Prevention, Beijing, China; Shanghai Municipal Center for Disease Control and Prevention, Shanghai, China.

India: International Institute for Population Sciences, Mumbai, India.

Mexico: National Institute of Public Health, Cuernavaca, Mexico.

Russian Federation: National Research Institute of Public Health (FSBI, RAMS) Moscow, Russian Federation.

South Africa: Human Sciences Research Council, Pretoria, South Africa; University of the Witwatersrand, Johannesburg, South Africa.

\section{Consent for publication}

\section{Not applicable.}

\section{Competing interests}

Lee JT is an editorial board member of BMC Public Health, but he had no role in the editorial process of this paper.

\section{Author details}

'Saw Swee Hock School of Public Health, National University of Singapore, 12 Science Drive 2, Tahir Foundation Building, Singapore 117549, Singapore. ${ }^{2}$ Primary Care and Multimorbidity, Usher Institute of Population Health Sciences and Informatics, University of Edinburgh, Edinburgh, Scotland. ${ }^{3}$ Yong Loo Lin School of Medicine, National University of Singapore, Singapore, Singapore. ${ }^{4}$ Department of Primary Care and Public Health, School of Public Health, Imperial College London, London, England. ${ }^{5}$ Nossal
Institute for Global Health, Melbourne School of Population and Global Health, University of Melbourne, Melbourne, Australia.

Received: 20 May 2019 Accepted: 19 December 2019

Published online: 06 January 2020

\section{References}

1. Jackson CA, Dobson AJ, Tooth LR, Mishra GD. Lifestyle and socioeconomic determinants of multimorbidity patterns among mid-aged women: a longitudinal study. PLoS One. 2016;11(6):e0156804.

2. Lee JT, Hamid F, Pati S, Atun R, Millett C. Impact of noncommunicable disease multimorbidity on healthcare utilisation and out-of-pocket expenditures in middle-income countries: cross sectional analysis. PLoS One. 2015;10(7):e0127199.

3. Jackson CL, Hambleton SJ. Australia's health care homes: laying the right foundations. Med J Aust. 2017;206(9):380-1.

4. Klabunde CN, Potosky AL, Legler JM, Warren JL. Development of a comorbidity index using physician claims data. J Clin Epidemiol. 2000;53(12):1258-67.

5. Tey NP, Lai SL, Teh JK. The debilitating effects of chronic diseases among the oldest old in China. Maturitas. 2016:94:39-45.

6. Concepció V, Quintí F-B, Gemma F-M, et al. Prevalence, determinants and patterns of multimorbidity in primary care: a systematic review of observational studies. PLoS One. 2014;7:e102149.

7. Piette JD, Kerr EA. The impact of comorbid chronic conditions on diabetes care. Diabetes Care. 2006;29(3):725-31.

8. Ricci-Cabello I, Stevens S, Kontopantelis E, et al. Impact of the prevalence of concordant and discordant conditions on the quality of diabetes Care in Family Practices in England. Ann Fam Med. 2015;13(6):514-22.

9. Turner BJ, Hollenbeak CS, Weiner M, Ten Have T, Tang SS. Effect of unrelated comorbid conditions on hypertension management. Ann Intern Med. 2008;148(8):578-86.

10. Wong MC, Wang HH, Cheung CS, et al. Factors associated with multimorbidity and its link with poor blood pressure control among 223,286 hypertensive patients. Int J Cardiol. 2014;177(1):202-8.

11. Bähler C, Huber CA, Brüngger B, Reich O. Multimorbidity, health care utilization and costs in an elderly community-dwelling population: a claims data based observational study. BMC Health Serv Res. 2015;15:23.

12. Millett C, Palladino R, Tayu Lee J, Ashworth M, Triassi M. Associations between multimorbidity, healthcare utilisation and health status: evidence from 16 European countries. Age Ageing. 2016;45(3):431-5

13. Kowal P, Chatterji S, Naidoo N, et al. Data resource profile: the World Health Organization study on global AGEing and adult health (SAGE). Int J Epidemiol. 2012:41(6):1639-49.

14. Lloyd-Sherlock P, Beard J, Minicuci N, Ebrahim S, Chatterji S. Hypertension among older adults in low- and middle-income countries: prevalence, awareness and control. Int J Epidemiol. 2014;43(1):116-28.

15. Oei HH, Vliegenthart R, Deckers JW, Hofman A, Oudkerk M, Witteman JC. The association of rose questionnaire angina pectoris and coronary calcification in a general population: the Rotterdam coronary calcification study. Ann Epidemiol. 2004;14(6):431-6.

16. Sorlie PD, Cooper L, Schreiner PJ, Rosamond W, Szklo M. Repeatability and validity of the rose questionnaire for angina pectoris in the atherosclerosis risk in communities study. J Clin Epidemiol. 1996;49(7):719-25.

17. Kessler RC, Ustun TB. The world mental health (WMH) survey initiative version of the World Health Organization (WHO) composite international diagnostic interview (CIDI). Int J Methods Psychiatr Res. 2004;13(2):93-121.

18. Moussavi S, Chatterji S, Verdes E, Tandon A, Patel V, Ustun B. Depression, chronic diseases, and decrements in health: results from the World Health Surveys. Lancet (London, England). 2007;370(9590):851-8.

19. Visser H, le Cessie S, Vos K, Breedveld FC, Hazes JM. How to diagnose rheumatoid arthritis early: a prediction model for persistent (erosive) arthritis. Arthritis Rheum. 2002;46(2):357-65.

20. AlHW. Older Australia at a glance. 2018. https://www.aihw.gov.au/ reports/older-people/older-australia-at-a-glance/contents/summary. 19 December 2018

21. AlHW. Health Care Homes. 2018. https://www.health.gov.au/internet/main/ publishing.nsf/Content/health-care-homes. Accessed 8 June 2019.

22. Sowers JR, Epstein M, Frohlich ED. Diabetes, hypertension, and cardiovascular disease: an update. Hypertension (Dallas, Tex : 1979). 2001: 37(4):1053-9. 
23. Pizzol D, Veronese N, Quaglio G, et al. The association between diabetes and cataract among 42,469 community-dwelling adults in six low- and middle-income countries. Diabetes Res Clin Pract. 2019;147: 102-10.

24. Jeffery PK. Remodeling in asthma and chronic obstructive lung disease. Am J Respir Crit Care Med. 2001;164(10 Pt 2):S28-38.

25. Zhang Y, Moran AE. Trends in the Prevalence, Awareness, Treatment, and Control of Hypertension Among Young Adults in the United States, 1999 to 2014. Hypertension (Dallas, Tex : 1979). 2017;70(4):736-42.

26. Mirza AA, Elmorsy SA. Diagnosis and control of hypertension as indicators of the level of awareness among relatives of medical students in Saudi Arabia. High Blood Press Cardiovasc Prev. 2016;23(2):123-32.

27. Shima A, Tatsumi Y, Ishizaki T, et al. Relationship between outpatient visit frequency and hypertension control: a 9-year occupational cohort study. Hypertens Res. 2016;39(5):376-81.

28. McConaghy JR, Oza RS. Outpatient diagnosis of acute chest pain in adults. Am Fam Physician. 2013;87(3):177-82.

29. Peeters GM, Alshurafa M, Schaap L, de Vet HC. Diagnostic accuracy of selfreported arthritis in the general adult population is acceptable. J Clin Epidemiol. 2015;68(4):452-9.

30. Martinez FJ, Mannino D, Leidy NK, et al. A new approach for identifying patients with undiagnosed chronic obstructive pulmonary disease. Am J Respir Crit Care Med. 2017;195(6):748-56.

31. Wang S, Gong W, Tian Y. Voluntary pulmonary function screening identifies high rates of undiagnosed asymptomatic chronic obstructive pulmonary disease. Chron Respir Dis. 2016;13(2):137-43.

32. Busby Grant J, Bruce CP, Batterham PJ. Predictors of personal, perceived and self-stigma towards anxiety and depression. Epidemiol Psychiatr Sci. 2016;25(3):247-54

33. Andrews JA, Astell AJ, Brown LJE, Harrison RF, Hawley MS. Technology for early detection of depression and anxiety in older people. Stud Health Technol Inform. 2017;242:374-80.

34. Pasina L, Brucato AL, Falcone $C$, et al. Medication non-adherence among elderly patients newly discharged and receiving polypharmacy. Drugs Aging. 2014;31(4):283-9.

35. Gellad WF, Grenard JL, Marcum ZA. A systematic review of barriers to medication adherence in the elderly: looking beyond cost and regimen complexity. Am J Geriatr Pharmacother. 2011;9(1):11-23.

36. Sum G, Hone T, Atun R, et al. Multimorbidity and out-of-pocket expenditure on medicines: a systematic review. BMJ Glob Health. 2018;3(1):e000505.

37. Brown MT, Bussell JK. Medication adherence: WHO cares? Mayo Clin Proc. 2011;86(4):304-14.

38. Marengoni A, Rizzuto D, Wang HX, Winblad B, Fratiglioni L. Patterns of chronic multimorbidity in the elderly population. J Am Geriatr Soc. 2009; 57(2):225-30.

39. Wagner EH. Meeting the needs of chronically ill people. Socioeconomic factors, disabilities, and comorbid conditions are obstacles. BMJ. 2001; 323(7319):945-6.

40. Barry MM, D'Eath M, Sixsmith J. Interventions for improving population health literacy: insights from a rapid review of the evidence. J Health Commun. 2013;18(12):1507-22.

41. Joplin S, van der Zwan R, Joshua F, Wong PKK. Medication adherence in patients with rheumatoid arthritis: the effect of patient education, health literacy, and musculoskeletal ultrasound. Biomed Res Int. 2015;2015:10.

42. Van den Broucke S. Health literacy: a critical concept for public health. Arch Public Health. 2014;72(1):10.

43. Nutbeam D. Health literacy as a public health goal: a challenge for contemporary health education and communication strategies into the $21 \mathrm{st}$ century. Health Promot Int. 2000;15(3):259-67.

44. Chatterji S, Kowal P. WHO Study on Global AGEing and Adult Health (SAGE): Wave 1, 2007-2010. Ann Arbor: Inter-university Consortium for Political and Social Research [distributor]; 2013. https://www.icpsr.umich.edu/icpsrweb/ NACDA/studies/31381/datadocumentation.

45. Vellakkal S, Millett C, Basu S, et al. Are estimates of socioeconomic inequalities in chronic disease artefactually narrowed by self-reported measures of prevalence in low-income and middle-income countries? Findings from the WHO-SAGE survey. J Epidemiol Community Health. 2015;69(3):218-25

46. Jones AR, Cook TM, Wang J. Rural-urban differences in stigma against depression and agreement with health professionals about treatment. J Affect Disord. 2011;134(1-3):145-50.
47. Lotufo PA, Malta DC, Szwarcwald CL, Stopa SR, Vieira ML, Bensenor IM. Prevalence of angina pectoris in the Brazilian population from the Rose questionnaire: analysis of the National Health Survey, 2013. Rev Bras Epidemiol. 2015;18(Suppl 2):123-31.

48. Achterberg S, Soedamah-Muthu S, Cramer M, Kappelle L, van der Graaf Y, Algra A. Prognostic value of the rose questionnaire: a validation with future coronary events in the SMART study. Eur J Prev Cardiol. 2012;19(1):5-14.

49. Graff-Iversen S, Selmer R, Løchen M-L. Rose angina predicts 23-year coronary heart disease mortality in women and men aged 40-49 years. Heart. 2008:94(4):482-6.

50. Lotufo P, Nunes MA, Brunoni A, Barreto SM, ALP R, Bensenor IM, et al. Eur Heart J. 2013;34(suppl_1)

51. Richiardi L, Bellocco R, Zugna D. Mediation analysis in epidemiology: methods, interpretation and bias. Int J Epidemiol. 2013;42(5):1511-9.

52. Grace Sum CS, Koh GC-H, Atun R, Oldenburg B, McPake B, Vellakkal S, Lee JT. Implications of multimorbidity patterns on health care utilisation and quality of life in middle-income countries: cross-sectional analysis. J Glob Health. 9(2)

53. Barnett K, Mercer SW, Norbury M, Watt G, Wyke S, Guthrie B. Epidemiology of multimorbidity and implications for health care, research, and medical education: a cross-sectional study. Lancet (London, England). 2012; 380(9836):37-43

54. Frieden TR. A framework for public health action: the health impact pyramid. Am J Public Health. 2010;100(4):590-5.

55. Waibel S, Vargas I, Coderch J, Vazquez ML. Relational continuity with primary and secondary care doctors: a qualitative study of perceptions of users of the Catalan national health system. BMC Health Serv Res. 2018;18(1):257.

56. Wright M, Mainous AG 3rd. Can continuity of care in primary care be sustained in the modern health system? Aust J Gen Pract. 2018:47(10):667-9.

57. Guthrie B. Continuity in UK general practice: a multilevel model of patient, doctor and practice factors associated with patients seeing their usual doctor. Fam Pract. 2002;19(5):496-9.

58. Dhillon RS, Bonds MH, Fraden M, Ndahiro D, Ruxin J. The impact of reducing financial barriers on utilisation of a primary health care facility in Rwanda. Glob Public Health. 2012;7(1):71-86.

59. Fox AM, Reich MR. The politics of universal health coverage in low- and middle-income countries: a framework for evaluation and action. J Health Polit Policy Law. 2015;40(5):1023-60.

60. Lagomarsino G, Garabrant A, Adyas A, Muga R, Otoo N. Moving towards universal health coverage: health insurance reforms in nine developing countries in Africa and Asia. Lancet (London, England). 2012;380(9845):933-43.

61. Witticke D, Seidling HM, Lohmann K, Send AF, Haefeli WE. Opportunities to reduce medication regimen complexity: a retrospective analysis of patients discharged from a university hospital in Germany. Drug Saf. 2013;36(1):31-41.

62. Kovacevic SV, Miljkovic B, Culafic M, et al. Evaluation of drug-related problems in older polypharmacy primary care patients. J Eval Clin Pract. 2017;23(4):860-5.

63. Feng $\mathrm{XQ}$, Zhu LL, Zhou Q. Opioid analgesics-related pharmacokinetic drug interactions: from the perspectives of evidence based on randomized controlled trials and clinical risk management. J Pain Res. 2017;10:1225-39.

64. Vrdoljak D, Borovac JA. Medication in the elderly - considerations and therapy prescription guidelines. Acta Med Acad. 2015;44(2):159-68.

65. Stewart D, Mair A, Wilson M, et al. Guidance to manage inappropriate polypharmacy in older people: systematic review and future developments. Expert Opin Drug Saf. 2017;16(2):203-13.

66. Sultan A, Thuan JF, Avignon A. Primary prevention of cardiovascular events and type 2 diabetes: should we prioritize our interventions? Diabetes Metab. 2006:32(6):559-67.

67. Laiteerapong $\mathrm{N}$, Huang ES, Chin MH. Prioritization of care in adults with diabetes and comorbidity. Ann N Y Acad Sci. 2011;1243:69-87.

68. Hofer TP, Zemencuk JK, Hayward RA. When there is too much to do. J Gen Intern Med. 2004;19(6):646-53.

69. Chen $H$, Chen $Y$, Cui B. The association of multimorbidity with healthcare expenditure among the elderly patients in Beijing, China. Arch Gerontol Geriatr. 2018;79:32-8.

70. Pelcastre-Villafuerte BE, Meneses-Navarro S, Ruelas-Gonzalez MG, ReyesMorales H, Amaya-Castellanos A, Taboada A. Aging in rural, indigenous communities: an intercultural and participatory healthcare approach in Mexico. Ethn Health. 2017;22(6):610-30. 
71. Ahmed SM, Tomson G, Petzold M, Kabir ZN. Socioeconomic status overrides age and gender in determining health-seeking behaviour in rural Bangladesh. Bull World Health Organ. 2005;83(2):109-17.

72. Dror DM, Chakraborty A, Majumdar A, Panda P, Koren R. Impact of community-based health insurance in rural India on self-medication \& financial protection of the insured. Indian J Med Res. 2016;143(6):809-20.

73. Peng BL, Ling L. Association between rural-to-urban migrants' social medical insurance, social integration and their medical return in China: a nationally representative cross-sectional data analysis. BMC Public Health. 2019;19(1):86.

74. Moffat K, Mercer SW. Challenges of managing people with multimorbidity in today's healthcare systems. BMC Fam Pract. 2015;16:129.

\section{Publisher's Note}

Springer Nature remains neutral with regard to jurisdictional claims in published maps and institutional affiliations.

Ready to submit your research? Choose BMC and benefit from:

- fast, convenient online submission

- thorough peer review by experienced researchers in your field

- rapid publication on acceptance

- support for research data, including large and complex data types

- gold Open Access which fosters wider collaboration and increased citations

- maximum visibility for your research: over $100 \mathrm{M}$ website views per year

At $\mathrm{BMC}$, research is always in progress.

Learn more biomedcentral.com/submissions 